Uşak Üniversitesi Sosyal Bilimler Dergisi

$2014,7 / 3$

\title{
Müşteri İlişkileri Yönetiminin İnovasyon Stratejilerine Etkisi Üzerine Bir Araştırma
}

\author{
Aysel ERCIŞ̧* \\ Polat CAN*
}

\begin{abstract}
Özet
Günümüzde özellikle rekabetin etkisiyle inovasyona olan ihtiyaç gün geçtikçe artmaktadır. Firmaların bu rekabet ortamında hayatta kalmaları için sadece ürün ve hizmetlerde değil, aynı zamanda hem firma içerisinde hem de değişen müşteri istek ve ihtiyaçlarına göre rakiplerden farklı ve etkin olarak üstün müşteri değeri yaratabilmek amacıyla müşteri ilişkileri yönetiminin inovasyon stratejilerine olan etkisini bilmeleri gerekmektedir. İnovasyonun sürekliliği ve devamlılığını sağlamada organizasyon yapısı ve kültürünün etkili ve önemli olduğu düşünülmektedir. Bu çalışmanın amacı müşteri ilişkileri yönetiminin inovasyon stratejileri üzerindeki etkisini ölçmek ve stratejilerin firma performansına etkisini tespit etmektir. Bu amaç doğrultusunda yapılan araştırma İSO 2009 verilerine göre ilk 500 firmada uygulanmıştır. Verilerin analizinde frekans dağılımları, ortalama ve standart sapma, yapısal eşitlik modelleme analizleri yapılmıştır. Analizler sonucunda müşteri ilişkileri yönetiminin inovasyon stratejileri üzerinde etkisinin olduğu belirlenmiştir.
\end{abstract}

Anahtar Kelimeler: Müşteri İlişkileri Yönetimi, Kıyaslama, Müşteri Bilgi Süreci, Lider Kullanıcılar, İnovasyon Stratejileri.

\section{A Study on the Impact on Innovation Strategies of Customer Relationship Management}

\begin{abstract}
Nowadays, the need for innovation, especially the effect of competition is increasing day by day. Companies with products and services not only to survive in this competitive environment, but also within the company as well as to the needs of the ever changing customer needs and superior customer value as its competitors in order to create a different and
\end{abstract}

\footnotetext{
* Prof. Dr. Atatürk Üniversitesi, İktisadi ve İdari Bilimler Fakültesi

** Yrd. Doç. Dr. Uşak Üniversitesi, İletişim Fakültesi, polat.can@usak.edu.tr
} 
effective customer relationship management must be aware of the impact of innovation strategies. Organizational structure and culture of innovation in ensuring continuity and continuity is thought to be an effective and important. The aim of this study was to measure the impact on innovation strategies and strategies of customer relationship management is to determine the impact on firm performance. According to research conducted for this purpose the top 500 firms applied to ISO 2009. Data analysis, frequency distribution, mean and standard deviation, structural equation modeling analyzes were conducted. Impact on the result of the analysis determined that the innovation strategies of customer relationship management.

Keywords: Customer Relationship Management, Benchmarking, Customer Information Process, Lead Users, Innovation Strategies

\section{Giriş}

Günümüz ekonomileri, yeni teknolojilerin hızlı gelişmesine, yeni pazarların ortaya çıkmasına ve mevcut endüstrilere hızla yeni firmaların katılmasına şahitlik etmektedir. Değişen bu şartlar altında firmalar rekabetçi olabilmek ve küresel pazarların isteklerini karşılayabilmek için çeşitli çözüm yolları aramaktadır. Bu rekabette avantaj elde edebilen firmaların, inovasyona önem veren ve yenilikçi organizasyon kültürüne sahip olduğu görülmektedir.

İnovasyon, günümüz ekonomileri için sürdürülebilir büyümenin ve toplumsal refahın ana gücü haline gelmiştir. Pazar için bu denli önemli role sahip olan inovasyon hiç şüphesiz ekonomik sistemlerin içerisindeki oyuncular için de verimlilik, etkinlik, işlevsellik, kârlılık ve performans artışı sağlayabilmenin temel kavramı olarak değerlendirilmektedir. İnovasyonun ekonomik kalkınmayı sağlamadaki olumlu etkisine paralel olarak, toplumsal refahın ve bireylerin yaşam standartlarının gelişmesine katkı sağladığı söylenebilir.

Dünyada bölgesel ekonomilerin ağırlığının artması, ülkeler arası sınırların zayıflaması, ticari korumacılığın azalması, üretim miktarının artması ve kâr oranlarının düşmesi gibi gelişmeler sonucunda global rekabetin niteliği değişmekte ve gittikçe daha karmaşık hale gelmektedir. Bu karmaşık ortamda rekabet avantajı elde etmenin temel araçlarından birisi inovasyondur. İnovasyon sadece yeni fikirlerin, bilgilerin, icatların ve teknolojilerin ortaya çıkarılması ve kaliteli ürün sunulabilmesi olarak 
algılanmamalıdır. Çünkü inovasyonun en önemli özelliği, yukarıda sayılan yeniliklerin toplumsal ve ekonomik fayda yaratması ve bunların ticarileştirilmesidir. Bu nedenle inovasyon için yapılan yatırımların geri dönüşümünün sağlanması ve performansının artırabilmesi, ekonomik ve toplumsal bir değer üreterek etkin bir ticarileştirme sürecinin yürürlüğe konulmasıyla mümkün olmaktadır.

İnovasyonun ticarileştirilmesinde, etkin pazarlama stratejilerinin geliştirilmesi, bunu destekleyen örgütsel yapının oluşturulması, işlevsel ve dinamik inovasyon sisteminin kurulması gerekmektedir. İnovasyonun ticarileştirilmesi için bireysel, toplumsal, örgütsel bağlamda mevcutlardan ve alternatiflerden farklı özgün bazı değerlerin ilave edilmesi gerekmektedir. $\mathrm{Bu}$ değerler ürünün temel özelliklerinde olabileceği gibi fiyatı, kalitesi, üretim şekli, ambalajı, sunum şekli, sosyal özellikleri ve markası gibi birçok farklı alanlarda da yaratılabilir. Bu yeni değerlerin benimsenmesi ve yayılımının hızlı olabilmesi için verimli, etkili ve yeni pazarlama stratejilerine ihtiyaç duyulmaktadır.

İnovasyon stratejilerinin belirlenmesinde sektörel farklılıkların dikkate alınması yararlı olabilir. Çünkü sektörel olarak inovasyon için üstün ve zayıf olan yönler tespit edildikten sonra hangi alanlarda yeniliklere ağırlık verileceği kararının alınması rekabetçi üstünlükler açısından faydalı olmaktadır. Ayrıca sektörel gelişmişlik düzeylerinin farklı olmasıda stratejilerin farklılaştırılmasında önemli etkiye sahiptir. Firma düzeyindeki inovasyon stratejilerinde ise büyüklük, işgücü ve finansman kaynaklarının dikkate alınması organizasyonel inovasyonun başarısı ve yapılan yatırımların geri dönüşümü açısından önemli olmaktadır.

Ayrıca inovasyonun bilgi temelli süreç olması bu bilgilerin üretilmesi, paylaşılması, yeni teknoloji, ürün, hizmet ve süreçlere dönüştürülmesinin önemini arttırmaktadır. Günümüzde bilgi ve teknolojinin çok gelişmiş olmasına bağlı olarak, inovasyonun temelini oluşturan bilginin üretimi ve iletimi için firmaların dışa açık inovasyon yaklaşımı ve sistemini benimsemeleri uygun olacaktır. Ancak inovasyonu sadece teknoloji, ürün, hizmet ve süreç olarak sınırlandırmak doğru değildir. Çünkü yeni hammadde kaynaklarından üretime, müşteri ilişkilerinden pazarlara ve organizasyon yapısına kadar çok geniş yelpazede inovasyonun gerçekleştirildiği görülmektedir.

İnovasyon sürecinin etkili ve verimli olarak yönetilebilmesi için onu etkileyen faktörlerin neler olduğunun belirlenmesi gerekmektedir. Pazarlama bağlamında inovasyonu etkileyen süreçlerden biriside müşteri ilişkileri yönetimidir (Hanvanich, Droge ve Calatone, 2003:125). Müşteri ilişkileri yönetimi, müşterilerle kişisel ilişkilerin sağlanması, müşteri 
tatminin oluşturulması ve geliştirilmesi, tekrarlanan satışın yapılabilmesi, kârlı müşterilerin tanımlanması ve onlara yüksek seviyede hizmetin sağlanmasını amaç edinen firma stratejisidir (Eichorn, 2004:156). Bu sürecin inovasyon stratejilerine etkisinin tespit edilmesinden sonra önemli olan konu inovasyonun firmaya sağladığı performansın değerlendirilmesidir.

İnovasyon faaliyetlerinin sonuçlarının değerlendirilmesi, firmaya sağladığı katma değerinin hesaplanması açısından oldukça önemlidir. Ancak inovasyon faaliyetleri çok karmaşık yapıya sahip olmasından dolayı bununla ilgili ölçümlerin yapılmasında kullanılacak göstergelerin tespiti oldukça zordur. Bu konuda ülke bazında yapılan çalışmalar makro düzeyde bir fikir versede, sektör ve işletme bazında sağlıklı bir inovasyon ölçüm sisteminin geliştirilmesi için daha fazla çalışmaya ihtiyaç duyulmaktadır.

Taşıdığı öneme rağmen firmaları inovasyon konusunda isteksizliğe iten bazı riskler söz konusudur. Bunlar önemli ölçüde inovasyonun sürdürülebilirliğinin sağlanması ve başarı şansının düşük olmasından kaynaklanmaktadır. Sürdürülebilirliğin sağlanmasındaki en önemli engel teknolojik gelişmelerdir. Çünkü teknolojideki gelişmeler inovasyonun başkaları tarafından kısa sürede benzerlerinin ve taklidinin yapılabilmesi imkânını sağlamaktadır. Bu durum inovasyona önem veren firmaların aleyhine olmaktadır. Buna çözüm olarak bir taraftan fikri mülkiyetlerin korunmasına ilişkin düzenlemeler yapılırken diğer taraftan da taklidi zorlaştıracak önlemlerin firma tarafından alınması gerekmektedir.

İnovasyonun pazardaki başarısı ve performansının artırılması etkin pazarlama stratejilerine, inovatif organizasyon yapısı ve kültürüne bağlıdır. Ayrıca inovasyon stratejilerini etkileyen müşteri ilişkileri yönetimi önem taşımaktadır. İnovasyonla ilgili bu gerçekler ve sorunlardan hareketle bu çalışmada müşteri ilişkileri yönetiminin inovasyon stratejilerine etkileri incelenmişir. Çalışma iki bölümden oluşmaktadır. Birinci bölümde müşteri ilişkileri yönetimi ve inovasyon kavramları ele alınmıştır. İkinci bölümde, müşteri ilişkileri yönetiminin inovasyon stratejilerine etkilerini ortaya koymak amacıyla bir araştırma yapılmıştır. Çalışmanın sonucunda ise, elde edilen bulgular ışığında firmalara çeşitli önerilerde bulunulmuştur.

\section{Müşteri İlişkileri Yönetimi ve İnovasyon İlişkisi}

Günümüzde hemen hemen tüm sektörlerde rekabetin arttığı, yeni ürünlerin pazara girme sürelerinin kısaldığı ve kârın düştüğü pazar ortamında müşteriye daha etkin ulaşmak ve isteklerine uygun ürün ve hizmet üretmek büyük önem taşımaktadır (Henard ve Dacin, 2010:323). 
Teknolojinin gelişmesi ve aynı ürün grubunda çeşidin çok olması müşterilerin deneyebileceği ürün alternatifinin fazla olmasina neden olmaktadır. Bu durum ise rekabeti artırmaktadır. Firmaların içinde bulunduğu bu rekabet ortamı yeni stratejiler geliştirme ihtiyacını ve üründen önce müşteriye değer sunmayı gerektirmektedir. Bu bağlamda müşteri ilişkileri yönetimine değer katacak yaklaşım ve stratejilerin geliştirilme zorunluluğu inovasyonun önemini arttırmaktadır (Lagrosen, 2005:427).

Müşteri odaklı hale gelen firmalar, müşteriler için değer yaratan çözümleri bulmaya önem vermek zorundadırlar. Bu firmalar; ürünleri, hizmetleri ve süreçleri, müşterinin kalite ve tatmin beklentisine uygun şekilde farklılaştırmalıdırlar. Bu farklılaştırmayı sağlamak için gerekli olan ise inovasyondur. Birçok firma müşteri ilişkileri faaliyetlerinde inovasyon kavramını ve anlayışını odak noktaya yerleştirmiştir. Çünkü inovasyon sayesinde, müşteri isteklerini etkin ve verimli şekilde karşılayabilme yeteneğine sahip olacaktır (Doğan ve Kılıç, 2008:65).

İnovasyon, firmalara müşteri ilişkileri yönetimi alanında bazı avantajlar sağlar. Bunlar; müşteriye daha iyi servis imkanı sağlanması, isteklere hızlı ve doğru cevap verebilmesi, ürünler arası çapraz satış miktarının artırabilmesi, pazarlama ve satış sürecinin hızlandırmasıdır (Wen vd., 2003:41). Müşteri ilişkileri yönetiminde inovasyon faaliyetlerinin önemli olanları şunlardır; rakip ürünler ile kıyaslama (benchmarking), müşteri bilgi süreci yönetimi ve lider kullanıcılar ile işbirliği'dir. Bu çalışmada bunlar ele alınmıştır.

\section{Rakip Ürünler ile Kıyaslama}

Kıyaslama (benchmarking) yöntemi inovasyon yönetiminin başarısına katkı sağlayan unsurlardan bir tanesidir. Kıyaslama, firmanın mevcut performansının düzenli ve sistematik olarak incelenmesini, doğru ve yanlış uygulamalarının belirlenmesini sağlayan yöntemdir. Burada sektöründe başarılı firmalardan etkili ve verimli yöntemler alınarak modeller hazırlanır ve firmanın mevcut sistemi ile kıyaslaması yapılır (Bosso vd., 2010:2).

Kıyaslama yöntemi, firmaya rakiplerin farklı yönlerini görme imkanın verir. Fakat bu, kopyalama ya da aynen alma anlamına gelmez. Bir diğer ifadeyle kıyaslama, adepte et, aynen alma manasına da gelir (Li-Hua ve Simon, 2007:111). En basit anlamılla kıyaslama, firmalar arasındaki ortak olan uygulamaların karşılaştırılmasıdır (Dattakumar ve Jagadeesh, 2003:182). Buradan hareketle kıyaslama, firma performansının sektöründe en iyi olan ile karşılaştırılarak ölçülmesi, daha sonra en iyi olanın bunu nasıl 
sağladığının tespit edilmesidir. Buna ilaveten elde edilen bilgiler ışığında firmanın hedefleri, stratejileri ve uygulamalarının yeniden değerlendirilmesidir (Vorhies ve Morgan, 2005:84).

Kıyaslama uygulamalarının amaçları arasında pazar payı ve kârlılığın artırılması, verimliliğin yükseltilmesi, kalitenin geliştirilmesi ve sonucunda müşteri memnuniyetinin sağlanması sayılabilir. Bu amaçlara ulaşmak için inovasyon faaliyetlerinin önemi büyüktür (Carpinetti ve De Melo, 2002:247). Müşteriler, firmanın kıyaslama sürecine değerlendirmeleri ile katkıda bulunarak inovasyon için gerekli olan fikrin sağlanmasına yardımcı olurlar. Bu bağlamda kıyaslama, inovasyon faaliyetlerinde sürekliliğin sağlanması ve sürdürülebilir rekabet avantajının oluşmasında firma için hayati önem taşır. Yeni inovasyon fikirlerini elde edemeyen firmanın yok olması kaçınılmaz bir gerçektir. Ayrıca kıyaslama pazar araştırmalarının, pazar araştırmaları ise inovasyonun temelidir (Koller ve Salzberg, 2009:2).

Sonuç olarak avantaj ve dezavantajlarını göz önünde tutarak kıyaslama yapmaya karar vermeden önce firmanın buna bütün bölümleriyle hazır olması gerekir. Organizasyon yapısı, kıyaslamaya olanak sağlayacak şekilde oluşturulmalı ve gerektiğinde önemli değişikliklerin yapılmasına imkân sağlamalıdır (Kyrö, 2004:71).

\section{Müşteri Bilgi Süreci}

Bilgi, en önemli rekabet avantajı sağlamasına rağmen firmalar, bilgiyi dinamik şekilde nasıl yaratacakları ve yönetecekleri konusunda yeterliliğe sahip değillerdir. Firmaların geleneksel anlamda bilgiye yaklaşımı "enformasyon işleme" şeklindedir (Knudsen, 2007:119). Bu görüşe göre, firma ancak dış çevreden topladığı enformasyonu değerlendirerek yeni oluşan şartlara uyum sağlayabilmektedir. Ancak bu görüş rekabet avantajı sağlamak için yeterli değildir (Van Der Bij vd., 2003:164). Firmalar, iç ve dış çevreden faydalanıp problemleri, çözümleri, süreçleri ve çevreyi tekrar tanımlayarak bilgi ve enformasyonu yeniden oluşturabilirler (Yang, 2010:217).

Çeşitli yöntemlerle elde edilen ve zihinsel süreçten geçirilen algılananların benimsenmesi ve paylaşılması amacıyla çeşitli ortamlarda kayıt altına alınmasına bilgi denir (Subramaniam, 2006:543). Bilginin oluşumunda yaşadıkça kazanılan tecrübeler, yargılar, değerler, beklentiler, inançlar ve sezgiler önemli rol oynar. Bilgi insan aklının kavradığı ve benimsediği verilerin karar verme sürecinde kullanması için anlamlı 
biçimde şekillendirilmesidir (Lichtenthaler ve Ernst, 2009:373). Bilgi aynı zamanda enformasyonun zihinsel süreçten geçirilerek düzenlenmesi sonucu oluşturulan anlam bütünüdür. Günlük kullanımda çoğu zaman bilgi; inanç, değer yargısı, his, önsezi gibi birbirine benzeyen kavramlarla iç içe geçmiştir (Spithoven vd., 2010:364).

Bilgi, bilenlerin zihinsel yapılarında ortaya çıkmakta ve burada uygulamaya geçirilmektedir. Firmalarda ise bilgi, genellikle sadece belgelerde ya da depolarda değil, rutin çalışmalarda, süreçlerde, uygulamalarda ve normlarda kendini gösterir. Bilgi, firmalarda en az sermaye kadar önemli üretim faktörüdür (Mei ve Nie, 2007:157).

Bilgi Yönetimi; rekabetin kaçınılmaz olarak yaşandığı ve çevre koşullarının sürekli olarak değiştiği pazar ortamında genellikle değişen tüm şartlara ve koşullara uyum sağlamak, pazarda kalıcı olmak ve sahip oldukları yetenekleri de muhafaza etmek için ortak aklın kullandığı süreçtir. Bilgi yönetimini, inovasyon süreci içerisinde etkili şekilde üretebilen, uygulayabilen, saklayabilen ve yayabilen firmalar diğerlerine göre daha başarılı olurlar (Lawson vd., 2009:157).

İnovasyon için önemli olan unsur müşteri bilgi süreci yönetimidir. Müşteri bilgi süreci, inovasyon sürecinde müşteri ihtiyaç ve isteklerinin öğrenilmesi için yürütülen faaliyetler bütünüdür ( $\mathrm{Li}$, Merenda ve Venkatachalam, 2009:51). Bir diğer ifadeyle müşteri katılımı ile bilgi elde edilmesidir. Çünkü müşteri katılımı, yeni ürün geliştirmek için kritik öneme sahip inovasyon fikrinin oluşmasında gereklidir (Shani vd., 2003:139). Ayrıca, geleneksel pazar araştırma teknikleri ile yeni ürün fikrini elde etmek zorlaşmaktadır. $\mathrm{Bu}$ durum müşterilerden bilgi toplamayı zorunlu hale getirmektedir. Müşterilerden elde edilen bilgiler inovasyon sürecinin başlatılmasına ve artırımsal inovasyon stratejilerinin uygulanmasına yardımcı olmaktadır (Atuahene-Gima ve Wei, 2011:85). Ayrıca, müşteri bilgi süreci, firmanın geleceği ile ilgili konularda, doğru zamanda ve doğru yerde karar verilmesini sağlar. Üretimin verimliliğini arttırır. İnovasyon için gerekli olan kaynak aktarımını kolaylaştırır. Pazarda kalıcı olmaya yardımcı olur. Firma çalışanlarının sahip olduğu gizli kalmış bilginin ortaya çıkmasını, bilginin doğru kişilere ulaşmasını ve aktarımını sağlar (Van Der Bij vd., 2003:165).

Sonuç olarak, günümüzde müşterilerin ürünün kalitesini belirlemesinde ve ürüne ilave özellik kazandırılmasında rolü sürekli artmaktadır. Bir başka değişle firmalar müşterilerden elde ettikleri olumlu ve olumsuz bütün bilgilere önem vermektedirler (Grabher vd., 2008:261). Müşterilerin bilgi sürecine katılımları inovasyon faaliyetlerinin etkinliğini artırmakta ve bunun sonucunda ürünün kalitesi, şekli, özelliği, görünümü 
kısmen veya tamamen değişebilmektedir. Ayrıca ürün tamamen piyasadan kalkıp değişik şekilde yeniden sunulabilmektedir (Hanvanich vd., 2003:126).

\section{Lider Kullanıcılar ile İşbirliği}

Etkili inovasyon yeteneğine sahip olmak, firmanın sahip olabileceği en büyük rekabet avantajlarından biridir. Müşteri istek ve ihtiyacının doğru şekilde anlaşılması, yeni ürünlerin geliştirilmesine temel teşkil eder. Firmalar müşteri ihtiyaçlarının tespit ve değerlendirmesini başarılı şekilde gerçekleştirmek için uygun yöntemlere ihtiyaç duymaktadırlar. Doğru yöntem ve araçlar ile firmalar, inovasyon için gerekli olan bilgiyi toplanabilir, analiz edebilir ve değerlendirebilir (Von Hippel, 2005:136). Geleneksel pazar araştırma yöntemleri, geniş müşteri grubunun ihtiyaçlarını esas alır ve bu doğrultuda ürün hazırlar. Bu geleneksel yöntemler ileri teknoloji ürünleri gibi hızla değişiklik gösteren ürün gruplarında ve pazara yeni sunulmuş ürünlerde güvenilir sonuçlar vermemektedir (Torkkeli vd., 2002:20).

İnovasyon geliştirme sürecinde başarı oranını artırabilmek için müşterinin, sürecin her adımında daha sık yer alması gerekir. Çünkü, müşteri ilişkileri yönetimi bu esasa dayanır. Buna rağmen henüz birçok firma, bu sürece müşteriyi etkili şekilde dâhil etmemektedir. Müşterinin sürece katılımının sağlanmasına yardımcı olan en etkili yöntem lider kullanıcılardır (Lilien vd., 2002:1045).

Lider kullanıcılar, firmanın en önemli müşterisi olarak tanımlanmaktadır. Çünkü bunlar, gelecekti ihtiyaçları bugünden tahmin edebilmekte ve ayrıca ihtiyacın giderilmesi için üreticilere, yeni ürün kavramı ve tasarım ile ilgili bilgiler verebilmektedirler (Van Kleef vd., 2005:185). Bir başka ifadeyle, geleneksel yöntemde hedef pazarın ihtiyaçları tespit edilir ve firma tarafından ihtiyaçları gidermek için çözüm önerileri geliştirilir. Lider kullanıcılar vasıtasıyla bilgi toplamada ise hem ihtiyaçlar tespit edilir hemde bu ihtiyaçları gidermek için çözüm önerileri öğrenilmeye çalışılır (Olson ve Bakke, 2001:390).

Lider kullanıcılar vasıtasıyla yeni ürün geliştirme, oldukça yeni bir yaklaşımdır ve hızla gelişmektedir. Lider kullanıcı yöntemi, inovasyon sürecinin ilk adımında ortaya çıkmaktadır. Özellikle hızlı değişen sektörlerde sıkça kullanılmaktadır. Lider kullanıcılarla yapılan çalışmalar, odak grup tekniği veya müşteri panelinden daha fazla etkili olmaktadır. Çünkü lider kullanıcılar, zor işleri yapmak, zaman ayırmak ve firmayla yaratıcı ekip çalışması yapmak için isteklidirler (Yayla ve Yıldız, 2010-a:5). 
Lider kullanıcı yönteminin uygulama adımları şu şekilde siralanabilir (Mohr vd., 2010:200-203):

Lider kullanıcı özelliklerinin tanımlanması: Lider kullanıcılar, zaman içinde değişen ve pazardaki diğer müşterilerden önce hareket eden gruptur. Bu sebepten, firmalar amaçlarına uygun olan lider kullanıcıları belirlemeden önce, bunların eğilimlerini, ilgi alanlarını ve özelliklerini tespit etmelidirler (Schreier ve Prügl, 2008:333). Buradaki amaç, seçilmiş sektör ve üründe başarılı olmuş, teknolojideki değişimleri takip eden ve pazarı araştıran lider kullanıcıları bulmaktır. Çünkü lider kullanıcı ihtiyacına en iyi şekilde karşılayacak çözümleri bulmak ister. Lider kullanıcıların başarısı yeniliklerin müşteriler tarafından kabul görme hızına da bağlıdır (Franke vd., 2006:303).

Lider kullanıcilarm tanımlanması: Pazardaki trend ve fayda beklentileri belirlendikten sonra potansiyel pazar izlenir ve lider kullanıcılar tespit edilir. Ayrıca muhtemel lider kullanıcılar müşteri veri tabanları yardımı ile tespit edilebilir. Lider kullanıcıların sayıca yeterli olması, bunlarla temasa geçme ve ilk iletişimin kurulmaya çalışılır (Morrison vd., 2004:356).

Lider kullaniclar ile ürün kavramı olușturmak: $\mathrm{Bu}$ adımda, lider kullanıcılar yardımıyla ürün kavramı oluşturulur. Lider kullanıcıların tecrübeleriyle, ihtiyaçları karşılayacak yeni ürün kavramları oluşturulabilir. Mevcut ürünlerde değiş̧iklikler yapılabilir. Lider kullanıcılar, ihtiyaçlara çözüm bulabilmek için firmadaki bölümlerle birlikte çalışırlar (Olson ve Bakke, 2004:415).

Geliştirilen ürünün testi: Metodun son adımı, lider kullanıcılar tarafından geliştirilen ürün ve hizmetin, pazarda daha fazla müşteri tarafından test edilmesidir (Coyne, 2000:28). Lider kullanıcıların ihtiyaçları, pazarda bulunan diğer müşterilerin ihtiyaçlarıyla benzer olmayabilir. $\mathrm{Bu}$ nedenle lider kullanıcılar tarafından kabul gören ürün, hedef pazarda daha fazla müşteri tarafından değerlendirilerek başarı şansı arttırılabilir (Intrachooto, 2004:361).

Sonuç olarak, lider kullanıcı yöntemi, inovasyon süreci başlangıcından sonuna kadar üst yönetim tarafından desteklenmelidir. Daha sonra inovasyon için hedefler belirlenmelidir. Trendlerin tespit edilmesinde kısa yollar kullanılmamalıdır. Çünkü trendlerin tespit edilmesini sınırlandırmak lider kullanıcıların etkinliğini engelleyebilir (Mohr vd., 2010:200). Lider kullanıcıların tespit edilmesinde bilgi sistemleri önemlidir. Lider kullanıcı metodunun uygulanmasına, küçük gruplarla başlanılmalı ve daha sonra bu gruplar birleştirilerek daha geniş tartışma grupları oluşturulmalıdır. Son olarak, lider kullanıcılar tarafından benimsenen yeni 
ürünler, pazarda bulunan birçok müşteri tarafından test edilmelidir (Lüthje ve Herstatt, 2004:556).

\section{II. İnovasyon Stratejileri}

Genel olarak strateji, belirlenen amaca ulaşmak için izlenen yöntem ve yaklaşımlardır. Firma için ana strateji, ürününün pazarda kabulü, büyüme ve değişim isteği, kullanabileceği rekabet araçları, yeni pazarlara girmek için izleyeceği yollar ve kaynaklara erişim yöntemleri için güçlü yönlerini geliştirme ve zayıf yönlerini gidermeye yönelik belirlediği kavramsal çerçevedir (Gatignon ve Xuereb, 1997:80).

İnovasyon uzun yıllar firmaların stratejik planlarında ihmal edildi. $\mathrm{Bu}$ süre içerisinde stratejik planlarda öncelik verilen konular genellikle maliyetlerin düşürülmesiydi. Maliyetleri azaltmak ve etkin üretim yöntemleri oluşturmak, stratejilerin önemli unsurlarından biridir (CambraFierro vd., 2011:157). Ancak yapılacak inovasyonlar finansal ve stratejik amaçlara ulaşmakda firmaya güç kazandırır. Günümüzde inovasyon firmanın gelirlerinin artırılmasında, büyümede ve en önemlisi rekabet üstünlüğü sağlamada etkin yöntem olarak kabul edilmektedir (Durna, 2002:126).

Bir firmanın inovasyon açısından izleyebileceği stratejiler dokuz grupta toplanabilir. Ancak, bu grupları birbirinden keskin çizgilerle ayrıldığını söylemek zordur. Bu stratejiler bazen birbirleri ile karıştırılabilir. Firmanın yapısı, hedef pazarı, rekabet koşulları hangi tip inovasyon stratejilerinin kullanılacağı konusunda etkilidir. Ayrıca, firmanın finansal ve beşeri kaynakları, organizasyon kültürü ve dış çevre faktörleri inovasyon stratejisinin belirlenmesinde etkili olur (Artto vd., 2008:56). Saldırgan, savunmacı, taklitçi, bağımlı, geleneksel, fırsatları izleme, elde etme, keşifsel ve artırımsal olmak üzere dokuz tane inovasyon stratejisi vardır (İraz, 2005:107-111; Durna, 2002;124-144; Uzkurt, 2008:178-181; Freeman ve Soete, 2004:308-328; Tinoco, 2007:11-16). Bunlardan araştırmada kullanılan keşifsel ve arttırımsal inovasyon stratejilerini sirasiyla inceleyecek olursak:

\section{Keşifsel İnovasyon Stratejisi}

Keşifsel inovasyon stratejisi, yepyeni fikirlerle oluşan, daha önce hiç denenmemiş ürün, hizmet ya da süreçler için geliştirilen ve denenmemiş yöntemlerdir. Bu stratejide, tüketici davranışlarında köklü değişiklikler oluşturmak için yeni yöntemler geliştirme ve bunlara değer kazandırma söz konusudur (Lynn ve Akgün, 2001:376). 
Genellikle yoğun araştırma ve geliştirme çabaları sonucu ortaya çıkan, müşteri ya da endüstri için tamamen yeni olan yeniliklerdir. Keşifsel strateji, iş süreçlerinde yapılan yepyeni değişimlerdir (McDermott ve O'Connor, 2002:429). Örneğin, IBM tarafından bulunan ve masaüstü bilgisayarlarda kullanılmak amaciyla üretilen silikon germenyum cipler normal ciplerden dört kat daha güçlü ve daha az enerji harciyordu. Bu ciplerin sayesinde cep telefonları ve diz üstü bilgisayarların üretilmesi mümkün olmuştur.

Keşifsel inovasyon stratejisi tamamiyla yeni ürün ve hizmet sınıflarını, üretim ve dağıtım yöntemlerini içerir. Bu stratejide, teknoloji ve pazar bakımından belirsizlik oldukça fazladır. Çünkü pazar henüz daha bu tip ürün ya da hizmetlere hazır değildir. Pazarın tam manasıyla potansiyelini belirlemek zordur (Cheng ve Shiu, 2007:232). Bu stratejiyi uygulayacak olan firmanın çok büyük yatırımlar yapması gerekir. Ancak bu yatırımlara paralel olarak karşılaşılabileceği risklerde büyüktür (Tellis vd., 2009:7).

Keşifsel stratejinin temelini tamamen farklı, yeni mühendislik ve bilim ilkeleri oluşturur. Bu strateji, genellikle yeni pazarlara açılmak istendiğinde tercih edilir. Bu stratejinin devamını artırımsal strateji oluşturur (Zheng vd., 2005:45). Örneğin, pişirilmeden hazırlanabilen hazır çorba keşifsel stratejinin bir sonucudur. Bundan sonra bu çorbanın farklı çeşitlerinin olması ise artırımsal stratejinin ürünüdür.

$\mathrm{Bu}$ strateji, sadece ürün ve hizmetler için uygulanmaz. Üretim ve dağıtımda teknolojik bilginin tamamen değiştirilmesini yada teknolojinin yeni şeklinin oluşturulmasını da kapsayabilir (Lavie ve Rosenkopf, 2006:802). Keşifsel stratejinin teknoloji alanında uygulanmasının bazı dezavantajları vardır. Bunlar şu şekildedir: Pazar potansiyelinin değerlendirmesini yapmak oldukça zordur. Ayrıca yeni teknoloji ve buna bağlı olarak yeni teknik bilginin nereden elde edileceğini öğrenmek güçtür. Esnek bir yapıya sahiptir. Çok sayıda deney yapılmasını gerektirir. Uygulanması ve verimin alınması uzun zaman alır (O'Connor ve Ayers, 2005:24).

Keşifsel inovasyon stratejisinde proje süresi genel olarak on yıl veya daha fazladır. Bu stratejisinin döngüsü kesintilidir. Beklenmeyen durumlar meydana gelebilir ve buluşun yönü değişebilir. Ayrıca yeni fikir ve fırsatlar stratejinin uygulamasının bütün aşamalarında ortaya çıkabilir (Sandström ve Tingström, 2008186). Başlangıçta belirsizlik yüksektir ancak zaman içerisinde bu durum öğrenme ve iş modelleri yardımıyla giderilebilir. Dolayısıyla planlarda değişebilir (Keizer ve Hamlan, 2007:31). Proje süreci boyunca farklı kişiler ve bölümler sürece katılabilir veya süreçten ayrılabilir. Stratejinin uygulama süreci boyunca bütün firma bölümlerinin katılımının 
sağlanması faydalıdır. Bu sorumluluk bir tek bölüme bırakılmamalıdır (Benner, 2009:476).

Firmalar birkaç sebepten dolayı keşifsel inovasyon stratejisini tercih ederler. İlk olarak bu inovasyon stratejisinde başarılı olunursa yüksek kârlar elde edilir (Reinders vd., 2010:1128). İkinci olarak, pazarda ürünü ilk sunan olacağı için pazar lideri konumuna gelir. Pazar liderliği firmanın rekabet gücünü artırır. Ürün dizaynı, fiyatlandırma veya promosyon faaliyetlerinde rakiplerin sahip olmadığı yeni bilgilere sahip olur. Bu strateji pazarlamacılar için önemlidir. Çünkü firmalar ürün-pazar stratejilerinde pazarlama bölümünün fikirlerine daha fazla önem verir ve pazarlama yöneticilerinin inovasyon kararlarında aktif rol oynamalarını sağlar (Matheus, 2009:257).

Sonuç olarak keşifsel inovasyon stratejisi daha önce mevcut olmayan pazar oluşturulmasına yönelik olduğu için düzeni değiştiren yeniliklerdir (Beverland vd., 2010:39). Firma bu stratejide kendi pazarını oluşturur. İlk ve tek olmanın avantajını kullanır ve rakipler pazara girinceye kadar ticari anlamda büyük başarı sağlar. Rekabet ortamı oluştuğunda ise öncü firma pazara iyice yayılmış olduğundan liderliğini korumakta zorlanmaz (Reid ve De Brentani, 2004:174).

\section{Artırımsal İnovasyon Stratejisi}

Artırımsal inovasyon stratejisi, mevcut olan ürün ve süreçlerin geliştirilmesidir. Bir diğer ifadeyle, firmanın mevcut uygulamalarında küçük değişikliklerin yapılmasıdır (Ottenbacher ve Harrington, 2007:446). Bu strateji, mevcut işlem, ürün ve hizmetleri geliştirmek ve genişletmek için yapılan küçük düzenleme ve iyileştirmelerdir. Ayrıca, rutin gelişmeler olarak da bilinen, genellikle küçük araştırma gerektiren ve bilinen teknoloji kullanılarak oluşturulan küçük mühendislik değişiklikleri de kapsar (Yalcinkaya vd., 2007:74).

Bu strateji, etkileyici ve yeni olan bilgiden kaynaklanmasa da önemli beceri ve ustalıklar gerektirir. Sistematik olarak keşifsel strateji ile geliştirilen ürün, daha sonrasında artırımsal inovasyona geçilebilinir (Bhaskaran, 2006:67). Örneğin cep telefonu keşifsel inovasyon stratejileri sayesinde oluşturulmuştur. Fakat cep telefonuna fotoğraf çekebilme özelliğinin eklenmesi artırımsal stratejiler sayesinde olmuştur.

Artırımsal stratejide ürünün orijinal şekli, temel kavram ve unsurları ile kullanım amacı değiştirilmez ama tasarımında nispeten değişiklikler yapılabilir. Ayrıca ürüne ilave özellikler katılabilir veya mevcut ürün hattı 
genişletilebilir. Yine ürün maliyetleri azaltılabilir ya da buna ilaveten ürünün kalitesi artırılabilir (Muscio, 2006:293).

Artırımsal inovasyon stratejisi, sürekli yapılan ürün ve süreç iyileştirmeleridir. Bu stratejide proje süresi altı ayla iki yıl arasında değişir. Genel olarak sektörde faaliyete gösteren firmalar tarafından kolaylıkla uygulanabilir ve rekabet konumun korunmasını sağlayabilir. Pazarda belirsizlik fazla olmadığı için ayrıntılı bir planlama yapılabilir (Vermeulen, 2005:435).

Sonuç olarak, firmalar yaşamlarını etkili ve verimli bir şekilde sürdürmek için yeni ürünlere ihtiyaç duyarlar. Bu yepyeni bir ürün olabileceği gibi mevcut ürünü veya ürün hattını geliştirme şeklinde de olabilir. Artırımsal stratejiyi keşifsel olandan farklılaştıran en önemli özellik mevcut ürünlerin temel kullanım amacının değiştirmemesidir (Lisboa vd., 2011:1158).

\section{Müşteri İlişkileri Yönetiminin İnovasyon Stratejilerine Etkisi Üzerine Bir Araştırma}

\section{Araştırmanın Konusu ve Amacı}

İnovasyon, günümüzde sürdürülebilir büyümenin sağlanması ve toplumsal refahın artırılmasında itici güç haline gelmiştir. Pazar için bu denli önemli role sahip olan inovasyon, firmalar için verimlilik, kârlılık ve performans artışının sağlanmasında temel unsur olarak değerlendirilmektedir. Buna ilaveten, inovasyon, sürdürülebilir büyüme aracı olarak görülmekte ve işletmelere yaratıcı, enerjik bir çalışma ortamı hazırlarken yeni istihdam olanakları da yaratmaktadır.

İnovasyonu sadece yeni fikirlerin, bilgilerin, buluşların ve teknolojilerin ortaya çıkarılması olarak algılamak doğru bir yaklaşım değildir. Çünkü inovasyonun toplumsal ve ekonomik fayda yaratabilmesi için ticari anlam kazanması gerekmektedir. $\mathrm{Bu}$ nedenle yapılacak yatırımların geri dönüşümünün sağlanması ve performansının artırılabilmesi etkili bir ticarileştirme sürecinin uygulanmasıyla mümkün olmaktadır.

Firmaların, müş̧teri ile temas sırasında topladığı verileri değerlendirebilmesi, sağlıklı analiz yapabilmesi ve amaçlarına uygun kararları zamanında alabilmesi müşteri ilişkileri yönetiminin temelini oluşturmaktadır. Müşterilerin ilişkide neye değer verdikleri ve hangi değerlerin özel öneme sahip olduğunu öğrenmek önemli olmaktadır. Firmaların müşteride bağlllık ve hizmetlerde etkinlik sağlayabilmesi ve devam ettirebilmesi için onlar hakkında ayrıntılı bilgiye sahip olmaları gerekmektedir. Bu kadar önemli olan müşteri ilişkileri yönetimimin 
inovasyon stratejilerine etkisinin dikkatlice tespit edilmesi gerekmektedir. $\mathrm{Bu}$ gereklilik bağlamında araştırmanın amacını, müşteri ilişkileri yönetiminin inovasyon stratejilerine etkisinin belirlenmesi oluşturmaktadır.

\section{Araştırmanın Değişkenleri}

Araştırma üç grup değişkenden oluşmaktadır. Birinci gruptaki değişkenler cevaplayıcıların demografik özellikleri, ikinci grup değişkenler firmaların özelliklerini ve üçüncü gruptaki ifadeler ise müşteri ilişkileri yönetimi girdi değişkeni, inovasyon stratejileri ara değişken ve firma performansına yönelik ifadeler ise çıktı değişkeni olarak belirlenmiştir.

Demografik özellikler, yaş, cinsiyet, eğitim durumu, firmadaki konumu ve çalışma süresinden oluşan beş değişkeni kapsamaktadır. Firma özellikleri ise, çalışan sayısı, faaliyet süresi, sermaye yapısı, patentli ürün sayısı, icat edilen ürün sayısı ve geliştirilen ürün sayısı değişkenlerinden oluşmaktadır.

Müşteri ilişkileri yönetimi ise müşteri bilgi süreci, rakipler ile kıyaslama ve lider kullanıcılar ile işbirliğgini değişkenlerinden oluşmaktadır. Bu grupta yer alan ifadeler 5'li likert ölçeğinden faydalanılarak ölçülmüştür. Araştırmada kullanılan ölçekler, yararlanılan kaynaklar ve ölçeklerde yer alan ifade sayıları aşağıdaki tabloda gösterilmiştir. 
Tablo 1: Araştırmada Kullanılan Ölçekler

\begin{tabular}{|l|l|c|}
\hline Değişkenler & Kaynaklar & $\begin{array}{c}\text { Ölçekte } \\
\text { Yer Alan } \\
\text { İfade } \\
\text { Sayıs1 }\end{array}$ \\
\hline $\begin{array}{l}\text { Rakipler İle } \\
\text { Kiyaslama }\end{array}$ & $\begin{array}{l}\text { Fredericks (2002), Gresham (2005), Matzler vd. } \\
\text { (2008), Ledwith ve O'Dwyer (2009) }\end{array}$ & 7 \\
\hline $\begin{array}{l}\text { Müşteri Bilgi } \\
\text { Süreci }\end{array}$ & $\begin{array}{l}\text { Li ve Calantone (1998), Zacharia (2001), } \\
\text { Cuthill (2001), Roupe (2003), Wei (2006), } \\
\text { Atuahene-Gima ve Wei (2011) }\end{array}$ & 6 \\
\hline $\begin{array}{l}\text { Lider } \\
\text { Kullanıcılar } \\
\text { İle İşbirliği }\end{array}$ & $\begin{array}{l}\text { Jayachandran vd. (2004), Roberts (2009), Kim } \\
\text { ve Atuahene-Gima (2010), Yayla ve Ylldız } \\
\text { (2010-a) }\end{array}$ & 4 \\
\hline $\begin{array}{l}\text { Keşifsel } \\
\text { İnovasyon } \\
\text { Stratejisi }\end{array}$ & $\begin{array}{l}\text { Katila ve Ahuja (2002), He ve Wong (2004), } \\
\text { Alegre vd. (2006), Cerdan vd. (2008), Sharp } \\
\text { (2009) }\end{array}$ & 7 \\
\hline $\begin{array}{l}\text { Artırımsal } \\
\text { İnovasyon } \\
\text { Stratejisi }\end{array}$ & $\begin{array}{l}\text { Katila ve Ahuja (2002), He ve Wong (2004), } \\
\text { Alegre vd. (2006), Cerdan vd. (2008) }\end{array}$ & 10 \\
\hline $\begin{array}{l}\text { Firma } \\
\text { Performansı }\end{array}$ & $\begin{array}{l}\text { Henderson (1999), Han vd. (2001), Vincent vd. } \\
\text { (2004), Swan vd. (2005), Salavou ve Avlonitis } \\
\text { (2008) }\end{array}$ & 6 \\
\hline Toplam & \multicolumn{2}{|l|}{} \\
\hline
\end{tabular}

\section{Araştırmanın Modeli}

Araştırma modeli aşağıdaki Şekil 1'de gösterilmiştir.

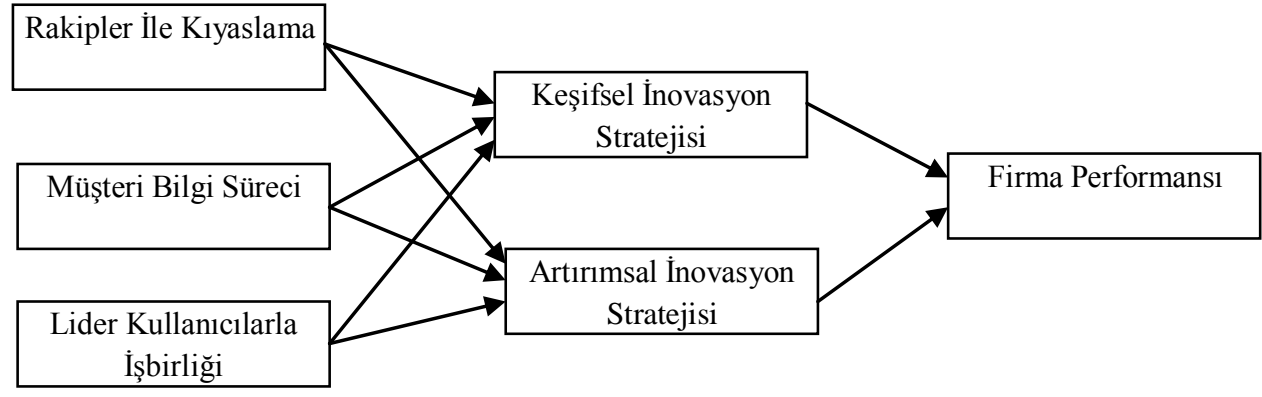

Şekil 1: Araştırmanın Modeli

Araştırma modelinde girdi değişkenleri, rakipler ile kıyaslama (benchmarking), müşteri bilgi süreci ve lider kullanıcılar (lead users) ile işbirliği değişkenlerinden oluşmaktadır. Pazar temelli öğrenme sürecinde 
firmalar kendi ürünleri ile rakiplerinin ürünleri arasında sürekli bir kıyaslama yapmaktadırlar. Bu kıyaslama sonucunda kendileri ürünlerini daha iyi geliştirebilmekte ve bunun sonucu olarak da pazarda rekabet üstünlüğü sağlamaktadırlar. Müşteri bilgi süreci, müşterilerin mevcut ve potansiyel ihtiyaçlarını karşılamak için üretilen veya geliştirilen ürüne karşı oluşan olumlu veya olumsuz davranışların öğrenilmesidir. Lider kullanıcılar ile işbirliği inovasyon için gerekli olan mevcut ve potansiyel ihtiyaçları öğrenmek için lider kullanıcılardan bilgi edinme davranışıdır. Modelde keşifsel ve artırımsal stratejilerden oluşan inovasyon stratejileri ara değişkeni oluşturmaktadır. Keşifsel inovasyon stratejisi, mevcut veya tamamen yeni yöntemlerle (pazarlama, tedarik, üretim, müşteri ilişkileri vb.) yeni bir ürün icat etmek ve bu ürünü pazara sunmaktır. Artırımsal inovasyon stratejisi ise, ürünün özelliklerinde veya üretim, tedarik, dağıtım vb. pazara sunum yöntemlerinde küçük değişiklikler yapmaktır. Araştırma modelinin çıktı değişkeni ise firma performansıdır.

\section{Araştırmanın Hipotezleri}

Araştırma amacı ve modeli doğrultusunda geliştirilen hipotezler aşağıda sıralanmıştır.

H1: Müşteri ilişkileri yönetimi inovasyon stratejilerini etkilemektedir.

H1a: Rakipler ile kıyaslama keşifsel inovasyon stratejisini etkilemektedir.

H1b: Müşteri bilgi süreci keşifsel inovasyon stratejisini etkilemektedir.

H1c: Lider kullanıcılarla işbirliği keşifsel inovasyon stratejisini etkilemektedir.

H1d: Rakipler ile kiyaslama artırımsal inovasyon stratejisini etkilemektedir.

H1e: Müşteri bilgi süreci artırımsal inovasyon stratejisini etkilemektedir.

H1f: Lider kullanıcılarla işbirliği artırımsal inovasyon stratejisi etkilemektedir.

H2: İnovasyon stratejileri firma performansını etkilemektedir.

H2a: Keşifsel inovasyon stratejisi firma performansını etkilemektedir.

$\mathrm{H} 2 \mathrm{~b}$ : Artırımsal inovasyon stratejisi firma performansını etkilemektedir.

\section{Veri Toplama Yöntem ve Aracı}

Araştırmada birincil elden veri toplama aracı olarak, kapalı uçlu soruların yer aldığı ve soruların önceden hazırlandığı anket yöntemi kullanılmıştır. Anket formu ilk olarak firmaların e-mail adreslerine gönderilmiştir. Bu yöntem ile yeterli sayıda veri elde edilememiştir. Daha sonra telefon ile anket uygulaması yöntemi uygulanmış ve bu yöntemde de 
yeterli veri elde edilememiştir. Son olarak anketler, cevaplayıcılar ile yüz yüze görüşme şeklinde uygulanmıştır.

Araştırma formunda 3 grup soru yer almıştır. Bunlardan birinci grup müşteri ilişkileri yönetimi, inovasyon stratejileri ve firma performansına yönelik düşünceleri ölçmek amacıyla hazırlanmıştır. Bu gruptaki sorular 5'li Likert ölçeği kullanılarak hazırlanmıştır. İkinci grup sorularda cevaplayıcıların demografik özellikleri yer almıştır. Üçüncü grup sorularda ise firmaların özellikleri ile ilgili bilgiler elde edilmeye çalışılmıştır. Veriler, SPSS 16.0 ve Lisrel 8.7 istatistik programları yardımıla analiz edilmiştir. Verilerin analizinde; aritmetik ortalama, frekans dağılımı, doğrulayıcı faktör analizi ve Yapısal Eşitlik Modelleme-Path Analizinden yararlanılmıştır.

\section{Cevaplayıcıların Demografik Özellikleri}

Aşağıdaki tabloda araştırmaya katılan firmalardaki cevaplayıcıların demografik özellikleri gösterilmiştir.

Tablo 2: Cevaplayıcıların Demografik Özellikleri

\begin{tabular}{|l|l|l|l|l|l|}
\hline Firmadaki Konum & Frekans & Yüzde & Yaş & Frekans & Yüzde \\
\hline CEO & - & - & $26-30$ & 8 & 4,0 \\
\hline Genel Müdür & 1 & 0,5 & $31-35$ & 23 & 11,6 \\
\hline Üst Düzey Yönetici & 27 & 13,6 & $36-40$ & 62 & 31,3 \\
\hline Pazarlama Müdürü & 79 & 39,9 & $41-45$ & 73 & 36,9 \\
\hline Ar\&Ge Müdürü & 29 & 14,6 & $46-50$ & 29 & 14,7 \\
\hline Satış Müdürü & 40 & 20,3 & 51 ve üzeri & 3 & 1,5 \\
\hline Üretim Müdürü & 22 & 11,1 & $\begin{array}{l}\text { Eğitim } \\
\text { Durumu }\end{array}$ & Frekans & Yüzde \\
\hline Diğer & - & - & Lise & 1 & 0,5 \\
\hline Çalısma Süresi (YIL) & Frekans & Yüzde & Yüksek Okul & 31 & 15,7 \\
\hline $0-4$ & 11 & 5,6 & Üniversite & 122 & 61,6 \\
\hline $5-9$ & 22 & 11,1 & Lisansüstü & 44 & 22,2 \\
\hline $10-14$ & 41 & 20,7 & Cinsiyet & Frekans & Yüzde \\
\hline $15-19$ & 71 & 35,8 & Kadın & 40 & 20,2 \\
\hline 20 yıl ve üzeri & 53 & 26,8 & Erkek & 158 & 79,8 \\
\hline TOPLAM & 198 & 100 & TOPLAM & 198 & 100 \\
\hline
\end{tabular}

Cevaplayıcıların \%39,9'u pazarlama müdürü, \%20,3'ü satış müdürü, $\% 14,6$ 's1 Ar\&Ge müdürü, \%13,6's1 üst düzey yönetici, \%11,1'i üretim müdürüdür. Cevaplayıcıların firmadaki çalışma sürelerine bakıldığında 
\%35,8'i 15-19 yıl, \%26,8'i 20 yıl ve daha fazla, \%20,7'si 10-14 yıl, \%11,1'i 5-9 yıl ve \%5,6'sı 0-4 yıl arasıdır. Cevaplayıcıların \%79,8'i erkeklerden, \%20.2'si ise kadınlardan oluşmaktadır. \%36,9'u 41-45, \%31,3'ü 36-40, \%14,7'si 46-50, $\% 11,6$ 's1 31-35, \%4'ü 26-30 ve \%1,5'i 51 ve üzeri yaş grubunda yer almaktadırlar. Eğitim durumlarına göre cevaplayıcıların \%61,6'sı üniversite, $\% 22,2$ 'si lisansüstü, $\% 15,7$ 'si yüksekokul ve $\% 0,5$ 'i lise eğitimine sahiptir.

\section{Firmaların Özellikleri}

Tablo 3'de İstanbul Sanayi Odasinca 2009 verilerine göre belirlenmiş olan ilk 500 firma içerisinden anket formunu cevaplayan firmaların özellikleri gösterilmiştir. 
Tablo 3: Firmaların Özellikleri

\begin{tabular}{|c|c|c|c|c|c|}
\hline $\begin{array}{l}\text { Çalışan Sayısı } \\
\text { (KIşsi) }\end{array}$ & Frekans & Yüzde & $\begin{array}{l}\text { İcat Edilen Ürün } \\
\text { Sayısı }\end{array}$ & Frekans & Yüzde \\
\hline $0-99$ & - & - & Hiç & 27 & 13,6 \\
\hline $100-499$ & 49 & 24,7 & 1 & 37 & 18,7 \\
\hline 500-1999 & 117 & 59,1 & 2 & 44 & 22,2 \\
\hline $2000-4999$ & 25 & 12,6 & 3 & 29 & 14,6 \\
\hline $5000-9999$ & 4 & 2,1 & 4 & 36 & 18,2 \\
\hline $\begin{array}{l}10.000 \text { ve daha } \\
\text { fazla }\end{array}$ & 3 & 1,5 & 5 & 9 & 4,5 \\
\hline $\begin{array}{l}\text { Faaliyet Süresi } \\
\text { (YIL) }\end{array}$ & Frekans & Yüzde & 6 ve daha fazla & 16 & 8,2 \\
\hline $0-4$ & 1 & 0,5 & $\begin{array}{l}\text { Geliştirilen Ürün } \\
\text { Sayısı }\end{array}$ & Frekans & Yüzde \\
\hline $5-24$ & 34 & 17,2 & Hiç & 10 & 5,1 \\
\hline $25-49$ & 93 & 47,0 & 1 & 22 & 11,1 \\
\hline $50-74$ & 42 & 21,1 & 2 & 20 & 10,1 \\
\hline $75-99$ & 12 & 6,1 & 3 & 31 & 15,7 \\
\hline 100 ve üzeri & 16 & 8,1 & 4 & 28 & 14,1 \\
\hline $\begin{array}{l}\text { Patentli Ürün } \\
\text { Sayısı }\end{array}$ & Frekans & Yüzde & 5 & 28 & 14,1 \\
\hline Hiç & 34 & 17,2 & 6 ve daha fazla & 59 & 29,8 \\
\hline 1 & 38 & 19,2 & Sermaye Yapısı & Frekans & Yüzde \\
\hline 2 & 49 & 24,6 & Yüzde Yüz Yerli & 144 & 72,7 \\
\hline 3 & 20 & 10,1 & $\begin{array}{l}\text { Yüzde Yüz } \\
\text { Yabancı }\end{array}$ & 33 & 16,7 \\
\hline 4 & 13 & 6,5 & Karma & 21 & 10,6 \\
\hline 5 & 10 & 5,1 & $\begin{array}{l}\text { Ar\&Ge } \\
\text { Departmanı }\end{array}$ & Frekans & Yüzde \\
\hline \multirow[t]{2}{*}{6 ve daha fazla } & 34 & 17,2 & Evet & 166 & 83,8 \\
\hline & & & Hayır & 32 & 16,2 \\
\hline TOPLAM & 198 & 100 & TOPLAM & 198 & 100 \\
\hline
\end{tabular}

Tabloda görüldüğü üzere firmaların \%59,1'i 500-1999, \%24,7'si 100499, \%12,6's1 2000-4999, \%2,1'i 5000-9999 ve \%1,5'i 10000 ve daha fazla çalışana sahiptir. Firmaların \%47'si 25-49, \%21,1'i 50-74, \%17,2'si 5-24, \%8,1'i 100 ve üzeri, \%6,1'i 75-99 ve \%0,5'i 0-4 yıl arasında faaliyet göstermektedir. Sermaye yapısı açısından firmaların \%72,7'si yerli, \%16,7'si yabancı ve $\% 10,6$ 's1 karma sermayeye sahiptir. Firmaların \%83,8'inin Ar\&Ge bölümü 
mevcut $\% 16,2^{\prime}$ sinin ise yoktur. Araştırmaya katılan firmaların $\% 22,2^{\prime}$ si 2 , $\% 18,7^{\prime}$ si $1, \% 18,2$ 'si 4, \%14,6'sı 3, \%13,6'sı hiç, \%8,2'si 6 ve daha fazla ve $\% 4,5^{\prime}$ i 5 tane ürün icat etmişlerdir. \%29,8'i 6 ve daha fazla, \%15,7'si 3, \%14,1'i 4, \%14,1'i 5, \%11,1'i 1, \%10,1'i 2 ve \%5,1'i hiç ürün geliştirmemişlerdir. Firmaları \%24,6'sı 2, \%19,2'si 1, \%17,2'si 6 ve daha fazla, \%17,2'si hiç, $\% 10,1^{\prime}$ i 3, \%6,5'i 4 ve \%5,1 5 ürünün patentine sahiptir.

\section{Cevaplayıcıların Müşteri İlişkileri Yönetimine Yönelik Algılarının ve Düşüncelerinin Belirlenmesi}

Cevaplayıcılara, müşteri ilişkileri yönetimine yönelik algılarını belirlemek üzere 5'li Likert ölçeğinde (5=Tamamen Katıllyorum $1=$ Kesinlikle Katılmıyorum) hazırlanan ifadelere katılma dereceleri sorulmuştur. Değişkenlere uygulanan güvenirlik analizi sonucunda, rakipler ile kıyaslamada 2 ifade ve müşteri bilgi sürecinden 1 ifade ölçekten çıkarılmıştır. Cevaplayıcıların rakipler ile kıyaslama, müşteri bilgi süreci ve lider kullanıcılar ile işbirliğine yönelik tutum ortalamaları ve standart sapmaları belirlenmiş, sonuçlar Tablo 4'de gösterilmiştir. 
Sosyal Bilimler Dergisi 39

Tablo 4: Cevaplayıcıların Müşteri İlişkileri Yönetimine Yönelik Alg1 Ortalamaları

\begin{tabular}{|c|c|c|}
\hline Değişkenler & $\begin{array}{c}\text { Aritmetik } \\
\text { Ortalama }\end{array}$ & $\begin{array}{c}\text { Standart } \\
\text { Sapma }\end{array}$ \\
\hline \multicolumn{3}{|l|}{ Rakipler İle Kiyaslama $(\alpha=0,871)$} \\
\hline $\begin{array}{l}\text { RK2: Rakiplerimizin ürün stratejileri hakkında } \\
\text { düzenli olarak araştırma yaparız. }\end{array}$ & 4,143 & 0,712 \\
\hline $\begin{array}{l}\text { RK3: Müssterilerin rakiplerimizden satın aldığ } \\
\text { ürünleri düzenli olarak takip ederiz. }\end{array}$ & 3,905 & 0,885 \\
\hline $\begin{array}{l}\text { RK4: Sürekli olarak rakiplerimizin sahip olduğu yeni } \\
\text { ürünlerin neler olduğunu araştırırız. }\end{array}$ & 4,142 & 0,941 \\
\hline $\begin{array}{l}\text { RK5: Rakiplerimizin ürünleri hakkındaki elde } \\
\text { ettiğimiz bilgiler ürün dizaynımızı etkiler. }\end{array}$ & 3,952 & 0,901 \\
\hline $\begin{array}{l}\text { RK6: Rakiplerimiz sürekli olarak ürün özelliklerini } \\
\text { değiştirirler. }\end{array}$ & 3,405 & 0,963 \\
\hline \multicolumn{3}{|l|}{ Müşteri Bilgi Süreci $(\alpha=0,875)$} \\
\hline $\begin{array}{l}\text { MB1: Müşterilerin yeni ürünlere olan ihtiyacını } \\
\text { öğrenmek için düzenli olarak toplantılar yaparız. }\end{array}$ & 4,003 & 0,936 \\
\hline $\begin{array}{l}\text { MB3: Düzenli olarak müşteri bilgilerini analiz } \\
\text { ederiz. }\end{array}$ & 4,190 & 0,887 \\
\hline $\begin{array}{l}\text { MB4: Yeni ürün tasarımında müşterilerimizden } \\
\text { gelen eleştirilere önem veririz. }\end{array}$ & 4,428 & 0,996 \\
\hline $\begin{array}{l}\text { MB5: Yeni ürün fikirleri için düzenli olarak } \\
\text { müşterilerimizin fikirlerine başvururuz. }\end{array}$ & 4,142 & 0,912 \\
\hline $\begin{array}{l}\text { MB6: Müşterilerimizin ürün tercihleri çok az } \\
\text { değişiklik gösterir. }\end{array}$ & 3,619 & 0,787 \\
\hline \multicolumn{3}{|l|}{ Lider Kullanıcılarla İşbirliği $(\alpha=0,879)$} \\
\hline $\begin{array}{l}\text { LK1: Ürünlerimizin fonksiyonları ve deneyimlerini } \\
\text { değerlendirebilen müşterileri bilmek isteriz. }\end{array}$ & 4,334 & 0,979 \\
\hline $\begin{array}{l}\text { LK2: Lider kullanıcı yöntemini kullanma, } \\
\text { müşterilerimizin ihtiyaçlarını anlamak için daha iyi } \\
\text { veriler verir. }\end{array}$ & 4,002 & 0,836 \\
\hline $\begin{array}{l}\text { LK3: Firmamız, ürün geliştirme sürecinin ilk } \\
\text { adımından itibaren lider kullanıcıları bu sürece dahil } \\
\text { eder. }\end{array}$ & 4,140 & 0,835 \\
\hline $\begin{array}{l}\text { LK4: Pazarımızdaki müşterilerin yeni eğilimlerini } \\
\text { öğrenmek için lider kullanıcı yöntemini kullanırız. }\end{array}$ & 4,009 & 0,992 \\
\hline
\end{tabular}


Rakipler ile kıyaslamanın genel ortalaması 3,909 olup, en yüksek değer 4,143 ile "rakiplerimizin ürün stratejileri hakkında düzenli olarak araştırma yaparız" ifadesinde gerçekleşmiştir. İkinci sırada, 4,142 ortalama ile "Sürekli olarak rakiplerimizin sahip olduğu yeni ürünlerin neler olduğunu araştırırız" ifadesi yer almaktadır. Bu faktördeki en düşük değer 3,405 ortalama ile "rakiplerimiz sürekli olarak ürün özelliklerini değiştirirler" ifadesine aittir. Bu ortalamalara bakılarak firmaların, rakiplerinin ürünleri hakkında bilgi toplayıp kıyaslama yaptıkları söylenebilir.

Müşteri bilgi sürecinin genel ortalaması 4,076 olup, en yüksek ortalama 4,428 ile "yeni ürün tasarımında müşterilerimizden gelen eleştirilere önem veririz" ifadesinde gerçekleşmiştir. İkinci sırada 4,190 ortalama ile "düzenli olarak müşteri bilgilerini analiz ederiz" ifadesi, üçüncü sırada ise, 4,142 ortalama ile "yeni ürün fikirleri için düzenli olarak müşterilerimizin fikirlerine başvururuz" ifadesi yer almaktadır. En düşük ortalama ise 3,619 ile "müşterilerimizin ürün tercihleri çok az değişiklik gösterir" ifadesi yer almaktadır. Bu ortalamalara göre firmalar için müşteri bilgi sürecinin önemli olduğu söylenebilir.

Lider kullanıcı yönteminin genel ortalaması 4,121 olup, en yüksek ortalama 4,334 ile "ürünlerimizin fonksiyonları ve deneyimlerini değerlendirebilen müşterileri bilmek isteriz" ifadesinde gerçekleşmiştir. En düşük ortalama ise 4,002 ile "lider kullanıcı yöntemini kullanma, müşterilerimizin ihtiyaçlarını anlamak için daha iyi veriler verir" ifadesi yer almaktadır. Bu ortalamalara göre firmaların lider kullanıcı yöntemi algılarının yüksek olduğu söylenebilir.

\section{Cevaplayıcıların İnovasyon Stratejilerine Yönelik Algılarının ve Düşüncelerinin Belirlenmesi}

Firmalarının inovasyon stratejilerine yönelik algılarını belirlemek üzere 5'li Likert ölçeğinde (5=Tamamen Katılıyorum - 1=Kesinlikle Katılmıyorum) hazırlanan ifadelere katılma dereceleri sorulmuştur. Değişkenlere uygulanan güvenirlik analizi sonucunda, artırımsal inovasyon stratejisinden 3 ifade ölçekten çıkarılmıştır. Cevaplayıcıların keşifsel ve artırımsal inovasyon stratejilerine yönelik tutum ortalamaları ve standart sapmaları belirlenmiş, sonuçlar Tablo 5'de gösterilmiştir. 
Tablo 5: Cevaplayıcıların İnovasyon Stratejisine Yönelik Algı Ortalamaları

\begin{tabular}{|c|c|c|}
\hline Değişkenler & $\begin{array}{c}\text { Aritmetik } \\
\text { Ortalama }\end{array}$ & $\begin{array}{c}\text { Standart } \\
\text { Sapma }\end{array}$ \\
\hline \multicolumn{3}{|l|}{ Keşifsel İnovasyon Stratejisi $(\alpha=0,899)$} \\
\hline $\begin{array}{l}\text { KS1: Firmamız için pazara yepyeni ürün icat edip } \\
\text { sunmak önemlidir. }\end{array}$ & 3,736 & 1,295 \\
\hline $\begin{array}{l}\text { KS2: Keşifsel inovasyon için tamamen yeni ve } \\
\text { farklı yöntemler geliştiririz. }\end{array}$ & 3,737 & 1,071 \\
\hline $\begin{array}{l}\text { KS3: Yeni endüstri alanlarına girmek bizim için } \\
\text { önemlidir. }\end{array}$ & 3,526 & 1,189 \\
\hline $\begin{array}{l}\text { KS4: Keşifsel inovasyon firmamızın farklı birimleri } \\
\text { (Ar\&Ge, Pazarlama, üretim birimleri vb.) } \\
\text { tarafından gerçekleştirilir. }\end{array}$ & 4,003 & 1,381 \\
\hline $\begin{array}{l}\text { KS5: Birçok yeni ürün fikrini başarıyla hayata } \\
\text { geçiririz. }\end{array}$ & 3,631 & 1,269 \\
\hline $\begin{array}{l}\text { KS6: Yeni ürünlerimiz pazarda köklü değişimlere } \\
\text { (pazarlama, satı̧, üretim, tedarik, vb. alanlarda) } \\
\text { sebep olur. }\end{array}$ & 3,947 & 1,102 \\
\hline $\begin{array}{l}\text { KS7: Yeni ürün üretirken var olan üründe köklü } \\
\text { değişiklik yaparız. }\end{array}$ & 3,421 & 1,045 \\
\hline \multicolumn{3}{|l|}{ Artırımsal İnovasyon Stratejisi $(\alpha=0,821)$} \\
\hline $\begin{array}{l}\text { AS1: Firmamız için ürün yelpazesini genişletmek } \\
\text { önemlidir. }\end{array}$ & 4,021 & 0,951 \\
\hline $\begin{array}{l}\text { AS3: Ürün geliştirmek için mevcut teknolojik } \\
\text { bilgimizi yeniden kullanırız. }\end{array}$ & 3,968 & 0,868 \\
\hline $\begin{array}{l}\text { AS4: Ürün geliştirmek için halen kullanmakta } \\
\text { olduğumuz teknoloji ile yeni teknolojinin birleşimi } \\
\text { olan teknolojik sistemi tercih ederiz. }\end{array}$ & 3,652 & 1,089 \\
\hline AS5: Üretim esnekliğini arttırmaya önem veririz. & 4,231 & 0,783 \\
\hline AS6: Verimi arttırmak temel amacımızdır. & 4,442 & 0,865 \\
\hline $\begin{array}{l}\text { AS7: Hammadde tüketimini azaltmak için sürekli } \\
\text { araştırma yaparız. }\end{array}$ & 4,073 & 0,954 \\
\hline $\begin{array}{l}\text { AS8: Var olan ürünleri gerektiğinde yeniden } \\
\text { konumlandırırız. }\end{array}$ & 3,916 & 0,931 \\
\hline
\end{tabular}


Keşifsel inovasyon stratejisine ait ifadelerin genel ortalaması 3,714 olup, en yüksek değer 4,003 ile "keşifsel inovasyon firmamızın farklı birimleri (Ar\&Ge, Pazarlama, üretim birimleri vb.) tarafından gerçekleştirilir" ifadesinde gerçekleşmiştir. İkinci sırada, 3,947 ortalama ile "yeni ürünlerimiz pazarda köklü değişimlere (pazarlama, satış, üretim, tedarik, vb. alanlarda) sebep olur" ifadesi yer almaktadır. Bu faktördeki en düşük değer 3,421 ortalama ile "yeni ürün üretirken var olan üründe köklü değişiklik yaparız" ifadesine aittir.

Cevaplayıcıların artırımsal inovasyon stratejilerine yönelik algılarının genel ortalaması 4,043'dür. En yüksek ortalama 4,442 ortalama ile "verimi arttırmak temel amacımızdır" ifadesinde gerçekleşmiştir. İkinci sırada 4,231 ile "üretim esnekliğini arttırmaya önem veririz" ifadesi, üçüncü sırada ise, 4,073 ortalama ile "hammadde tüketimini azaltmak için sürekli araştırma yaparı" ifadesi yer almaktadır. Artırımsal inovasyon stratejisi ifadelerinden en düşük değeri ise 3,652 ortalama ile "Ürün geliştirmek için halen kullanmakta olduğumuz teknoloji ile yeni teknolojinin birleşimi olan teknolojik sistemi tercih ederiz" değişkeni almıştır. Ortalamalara göre artırımsal inovasyon stratejisi ifadeleri oldukça yüksek değere sahip olduğu söylenebilir.

\section{Cevaplayıcıların Firma Performansına Yönelik Algılarının ve Düşüncelerinin Belirlenmesi}

Cevaplayıcılara, firma performansına yönelik algılarını belirlemek üzere 5'li Likert ölçeğinde (5=Tamamen Katılıyorum - 1=Kesinlikle Katılmıyorum) hazırlanan ifadelere katılma dereceleri sorulmuştur. Cevaplayıcıların firma performansına yönelik tutum ortalamaları ve standart sapmaları belirlenmiş, sonuçlar Tablo $6^{\prime}$ da gösterilmiştir. 
Tablo 6: Cevaplayıcıların Firma Performansına Yönelik Algı Ortalamaları

\begin{tabular}{|l|c|c|}
\hline Firma Performansı $(\boldsymbol{\alpha}=\mathbf{0 , 8 2 1 )}$ & $\begin{array}{c}\text { Aritmetik } \\
\text { Ortalama }\end{array}$ & $\begin{array}{c}\text { Standart } \\
\text { Sapma }\end{array}$ \\
\hline $\begin{array}{l}\text { FP1: Son 5 yılda rakiplerimize göre, yeni ürün } \\
\text { geliştirme için yaptığımız yatırımların getirisi } \\
\text { daha iyidir. }\end{array}$ & 4,257 & 0,703 \\
\hline $\begin{array}{l}\text { FP2: Son 5 yılda rakiplerimize göre Pazar payımız } \\
\text { daha fazla artmıştır. }\end{array}$ & 4,208 & 0,681 \\
\hline $\begin{array}{l}\text { FP3: Son 5 yılda rakiplerimize göre satışlarımız } \\
\text { artmışıtır. }\end{array}$ & 4,253 & 0,642 \\
\hline $\begin{array}{l}\text { FP4: Son 5 yılda rakiplerimize göre satış } \\
\text { kârlılığımız daha iyidir. }\end{array}$ & 4,404 & 0,585 \\
\hline $\begin{array}{l}\text { FP5: Son 5 yılda yeni ürünün geliştirilmesi ile } \\
\text { hedeflenen kârlılık rakamlarına ulaşılmıştır. }\end{array}$ & 3,953 & 0,591 \\
\hline $\begin{array}{l}\text { FP6: Son 5 yılda rakiplerimiz ile kıyasladığımızda } \\
\text { yatırımlarımızın geri dönüşü daha fazladır. }\end{array}$ & 4,302 & 0,558 \\
\hline
\end{tabular}

Cevaplayıcıların firma performansına yönelik algılarının genel ortalaması 4,229'dur. En yüksek ortalama 4,404 ile "son 5 yılda rakiplerimize göre satış kârlılı̆̆ımız daha iyidir" ifadesinde gerçekleşmiştir. İkinci sırada 4,302 ortalama ile "son 5 yılda rakiplerimiz ile kıyasladığımızda yatırımlarımızın geri dönüşü daha fazladır" ifadesi, üçüncü sırada ise, 4,257 ortalama ile "son 5 yılda rakiplerimize göre, yeni ürün geliştirme için yaptığımız yatırımların getirisi daha iyidir" ifadesi yer almaktadır. Firma performansı ifadelerinden en düşük değeri ise 3,953 ortalama ile "son 5 yılda yeni ürünün geliştirilmesi ile hedeflenen kârlılık rakamlarına ulaşılmıştır" değişkeni almıştır. Ortalamalara göre firma performansına yönelik ortalamanın oldukça yüksek olduğu görülmektedir.

\section{Araştırmada Kullanılan Ölçeklerin Test Edilmesi}

Araştırma modelinde yer alan müşteri ilişkileri yönetiminin alt değişkenleri olan rakipler ile kıyaslama, müşteri bilgi süreci ve lider kullanıcılar ile işbirliği değişkenleri doğrulayıcı faktör analizi ile test edilmiştir. Rakipler ile kıyaslama (7 ifade), müşteri bilgi süreci (6 ifade) ve lider kullanıcılar ile işbirliğini (4 ifade) ölçmek amacıyla oluşturulan ölçeklerden güvenilirlik analizi sonucunda kalan rakipler ile kıyaslamadan 5 ifade, müşteri bilgi sürecinden 5 ifade ve lider kullanıcılar ile işbirliğinden 4 ifade analize tabi tutulmuştur. Aşağıda Tablo 7 'de müşteri ilişkisi yönetimini tespit etmekte kullanılan ölçeklerin modifikasyonlar sonrası uyum değerleri verilmiştir. 
Tablo 7: Müşteri İlişkileri Yönetimi Ölçeklerinin Modifikasyonlar Sonrası Uyum Değerleri

\begin{tabular}{|c|c|c|c|c|}
\hline & $\begin{array}{l}\text { Uyumluluk } \\
\text { İndeksleri }\end{array}$ & $\begin{array}{l}\text { Ölçeğin } \\
\text { Uyum } \\
\text { Değerleri }\end{array}$ & $\begin{array}{l}\text { Mükemmel } \\
\text { Uyum Değerleri }\end{array}$ & $\begin{array}{l}\text { Kabul Edilebilir } \\
\text { Uyum Değerleri }\end{array}$ \\
\hline \multirow{12}{*}{ 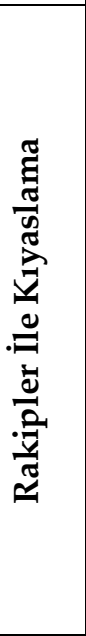 } & Ki-Kare $\left(\chi^{2}\right)$ & 3,01 & $0 \leq \chi^{2} \leq 2 \mathrm{df}$ & $2 \mathrm{df} \leq \chi^{2} \leq 3 \mathrm{df}$ \\
\hline & p değeri & 0,066 & $0,05<\mathrm{p} \leq 1,00$ & $0,01 \leq \mathrm{p} \leq 0,05$ \\
\hline & $\begin{array}{l}\text { Serbestlik } \\
\text { derecesi }(\mathrm{df})\end{array}$ & 2 & & \\
\hline & $\chi^{2} / \mathrm{df}$ & 1,5 & $0 \leq \chi^{2} / \mathrm{df} \leq 2$ & $2 \leq \chi^{2} / \mathrm{df} \leq 3$ \\
\hline & RMSEA & 0,067 & $0 \leq$ RMSEA $\leq 0,05$ & $0,05 \leq$ RMSEA $\leq 0,08$ \\
\hline & SRMR & 0,046 & $0 \leq \mathrm{SRMR} \leq 0,05$ & $0,05 \leq \mathrm{SRMR} \leq 0,10$ \\
\hline & NFI & 0,94 & $0,95 \leq \mathrm{NFI} \leq 1,00$ & $0,90 \leq \mathrm{NFI} \leq 0,95$ \\
\hline & NNFI & 0,96 & $0,97 \leq \mathrm{NNFI} \leq 1,00$ & $0,95 \leq \mathrm{NNFI} \leq 0,97$ \\
\hline & CFI & 0,95 & $0,97 \leq \mathrm{CFI} \leq 1,00$ & $0,95 \leq \mathrm{CFI} \leq 0,97$ \\
\hline & GFI & 0,97 & $0,95 \leq \mathrm{GFI} \leq 1,00$ & $0,90 \leq \mathrm{GFI} \leq 0,95$ \\
\hline & AGFI & 0,92 & $0,90 \leq \mathrm{AGFI} \leq 1,00$ & $0,85 \leq \mathrm{AGFI} \leq 0,90$ \\
\hline & IFI & 0,94 & $0,95 \leq \mathrm{IFI} \leq 1,00$ & $0,90 \leq \mathrm{IFI} \leq 0,95$ \\
\hline \multirow{12}{*}{ 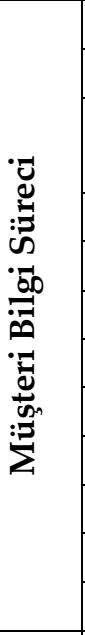 } & Ki-Kare $\left(\chi^{2}\right)$ & 4,61 & $0 \leq \chi^{2} \leq 2 \mathrm{df}$ & $2 \mathrm{df} \leq \chi^{2} \leq 3 \mathrm{df}$ \\
\hline & p değeri & 0,014 & $0,05<\mathrm{p} \leq 1,00$ & $0,01 \leq \mathrm{p} \leq 0,05$ \\
\hline & $\begin{array}{l}\text { Serbestlik } \\
\text { derecesi (df) }\end{array}$ & 2 & & \\
\hline & $\chi^{2} / \mathrm{df}$ & 2,30 & $0 \leq \chi^{2} / \mathrm{df} \leq 2$ & $2 \leq \chi^{2} / \mathrm{df} \leq 3$ \\
\hline & RMSEA & 0,079 & $0 \leq$ RMSEA $\leq 0,05$ & $0,05 \leq$ RMSEA $\leq 0,08$ \\
\hline & SRMR & 0,062 & $0 \leq \mathrm{SRMR} \leq 0,05$ & $0,05 \leq \mathrm{SRMR} \leq 0,10$ \\
\hline & NFI & 0,91 & $0,95 \leq \mathrm{NFI} \leq 1,00$ & $0,90 \leq \mathrm{NFI} \leq 0,95$ \\
\hline & NNFI & 0,96 & $0,97 \leq \mathrm{NNFI} \leq 1,00$ & $0,95 \leq \mathrm{NNFI} \leq 0,97$ \\
\hline & CFI & 0,95 & $0,97 \leq \mathrm{CFI} \leq 1,00$ & $0,95 \leq \mathrm{CFI} \leq 0,97$ \\
\hline & GFI & 0,96 & $0,95 \leq \mathrm{GFI} \leq 1,00$ & $0,90 \leq \mathrm{GFI} \leq 0,95$ \\
\hline & AGFI & 0,92 & $0,90 \leq \mathrm{AGFI} \leq 1,00$ & $0,85 \leq \mathrm{AGFI} \leq 0,90$ \\
\hline & IFI & 0,91 & $0,95 \leq \mathrm{IFI} \leq 1,00$ & $0,90 \leq \mathrm{IFI} \leq 0,95$ \\
\hline \multirow{5}{*}{ 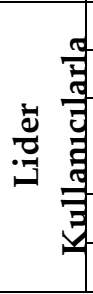 } & Ki-Kare $\left(\chi^{2}\right)$ & 3,87 & $0 \leq \chi^{2} \leq 2 \mathrm{df}$ & $2 \mathrm{df} \leq \chi^{2} \leq 3 \mathrm{df}$ \\
\hline & $\mathrm{p}$ değeri & 0,078 & $0,05<\mathrm{p} \leq 1,00$ & $0,01 \leq \mathrm{p} \leq 0,05$ \\
\hline & $\begin{array}{l}\text { Serbestlik } \\
\text { derecesi }(\mathrm{df})\end{array}$ & 2 & & \\
\hline & $\chi^{2} / \mathrm{df}$ & 1,93 & $0 \leq \chi^{2} / \mathrm{df} \leq 2$ & $2 \leq \chi^{2} / \mathrm{df} \leq 3$ \\
\hline & RMSEA & 0,046 & $0 \leq$ RMSEA $\leq 0,05$ & $0,05 \leq$ RMSEA $\leq 0,08$ \\
\hline
\end{tabular}


Sosyal Bilimler Dergisi 45

\begin{tabular}{|l|l|c|c|c|}
\hline SRMR & 0,021 & $0 \leq \mathrm{SRMR} \leq 0,05$ & $0,05 \leq \mathrm{SRMR} \leq 0,10$ \\
\hline NFI & 0,98 & $0,95 \leq \mathrm{NFI} \leq 1,00$ & $0,90 \leq \mathrm{NFI} \leq 0,95$ \\
\hline NNFI & 0,99 & $0,97 \leq \mathrm{NNFI} \leq 1,00$ & $0,95 \leq \mathrm{NNFI} \leq 0,97$ \\
\hline CFI & 1,00 & $0,97 \leq \mathrm{CFI} \leq 1,00$ & $0,95 \leq \mathrm{CFI} \leq 0,97$ \\
\hline GFI & 0,97 & $0,95 \leq \mathrm{GFI} \leq 1,00$ & $0,90 \leq \mathrm{GFI} \leq 0,95$ \\
\hline AGFI & 0,94 & $0,90 \leq \mathrm{AGFI} \leq 1,00$ & $0,85 \leq \mathrm{AGFI} \leq 0,90$ \\
\hline IFI & 0,99 & $0,95 \leq \mathrm{IFI} \leq 1,00$ & $0,90 \leq \mathrm{IFI} \leq 0,95$ \\
\hline
\end{tabular}

Rakipler ile kıyaslama, müşteri bilgi süreci ve lider kullanıcılarla işbirliğini oluşturan değişkenlerle ilgili yapılan modifikasyonlar sonrasında kalan değişkenlerin Cronbach's alfa değeri, standart katsayıları, $R^{2}$, t değerleri, yapı güvenilirliği ve açıklanan varyans oranı Tablo 8'de gösterilmiştir.

Tablo 8: Müşteri İlişkileri Yönetimini Oluşturan Ölçeklerin Değişkenlerine Ait Değerler

\begin{tabular}{|c|c|c|c|c|c|c|}
\hline \multirow{2}{*}{ Rakipler ile Kıyaslama } & $\alpha$ & YG & $\begin{array}{l}\text { AVO } \\
(\%)\end{array}$ & \multirow{2}{*}{$\begin{array}{l}\text { Standart } \\
\text { Değer }\end{array}$} & \multirow{2}{*}{$\mathbf{R}^{2}$} & \multirow{2}{*}{$\begin{array}{l}t \\
\text { değe } \\
\text { ri }\end{array}$} \\
\hline & 0,76 & 0,88 & 0,64 & & & \\
\hline $\begin{array}{l}\text { Rakiplerimizin ürün } \\
\text { stratejileri hakkında düzenli } \\
\text { olarak araştırma yaparız. }\end{array}$ & $\begin{array}{l}\text { RK } \\
2\end{array}$ & & & 0,78 & 0,61 & 11,20 \\
\hline $\begin{array}{l}\text { Müşterilerin rakiplerimizden } \\
\text { satın aldığı ürünleri düzenli } \\
\text { olarak takip ederiz. }\end{array}$ & $\begin{array}{l}\text { RK } \\
3\end{array}$ & & & 0,57 & 0,32 & 7,73 \\
\hline $\begin{array}{l}\text { Sürekli olarak rakiplerimizin } \\
\text { sahip olduğu yeni ürünlerin } \\
\text { neler olduğunu araştırırız. }\end{array}$ & $\begin{array}{l}\text { RK } \\
4\end{array}$ & & & 0,67 & 0,45 & 9,44 \\
\hline $\begin{array}{lr}\text { Rakiplerimiz } & \text { sürekli olarak } \\
\text { ürün } & \text { özelliklerini } \\
\text { değiştirirler. } & \end{array}$ & $\begin{array}{l}\text { RK } \\
6\end{array}$ & & & 0,71 & 0,51 & 10,12 \\
\hline \multirow{2}{*}{ Müşteri Bilgi Süreci } & $\alpha$ & YG & $\begin{array}{c}\text { AVO } \\
(\%)\end{array}$ & \multirow{2}{*}{$\begin{array}{l}\text { Standart } \\
\text { Değer }\end{array}$} & \multirow[t]{2}{*}{$\mathbf{R}^{2}$} & \multirow{2}{*}{$\underset{\text { değe }}{\mathbf{t}}$} \\
\hline & 0,76 & 0,80 & 0,51 & & & \\
\hline $\begin{array}{l}\text { Düzenli olarak müşteri } \\
\text { bilgilerini analiz ederiz. }\end{array}$ & $\begin{array}{c}\mathrm{MB} \\
3\end{array}$ & & & 0,66 & 0,44 & 8,53 \\
\hline $\begin{array}{l}\text { Yeni ürün tasarımında } \\
\text { müşterilerimizden } \quad \text { gelen }\end{array}$ & $\begin{array}{c}\mathrm{MB} \\
4 \\
\end{array}$ & & & 0,56 & 0,32 & 7,37 \\
\hline
\end{tabular}




\begin{tabular}{|c|c|c|c|c|c|c|}
\hline \multicolumn{7}{|l|}{ eleştirilere önem veririz. } \\
\hline $\begin{array}{l}\text { Yeni ürün fikirleri için } \\
\text { düzenli } \\
\text { müşterilerimizin } \\
\begin{array}{l}\text { başvururuz. } \\
\text { barlerine }\end{array}\end{array}$ & $\begin{array}{c}\mathrm{MB} \\
5\end{array}$ & & & 0,31 & 0,57 & 5,72 \\
\hline $\begin{array}{l}\text { Müşterilerimizin } \text { ürün } \\
\text { tercihleri çok az değişiklik } \\
\text { gösterir. }\end{array}$ & $\begin{array}{c}\mathrm{MB} \\
6\end{array}$ & & & 0,52 & 0,68 & 9,32 \\
\hline \multirow{2}{*}{$\begin{array}{ll}\text { Lider } & \text { Kullanıcılarla } \\
\text { İşbirliği } & \end{array}$} & $\alpha$ & YG & $\begin{array}{c}\text { AVO } \\
(\%)\end{array}$ & \multirow{2}{*}{$\begin{array}{l}\text { Standart } \\
\text { Değer }\end{array}$} & \multirow[t]{2}{*}{$\mathbf{R}^{2}$} & \multirow{2}{*}{$\underset{\text { değe }}{\mathrm{t}}$} \\
\hline & 0,76 & 0,80 & 0,51 & & & \\
\hline $\begin{array}{l}\text { Lider kullanıcı yöntemini } \\
\text { kullanma, müşterilerimizin } \\
\text { ihtiyaçlarını anlamak için } \\
\text { daha iyi veriler verir. }\end{array}$ & $\begin{array}{c}\mathrm{LK} \\
2\end{array}$ & & & 0,94 & 0,88 & 7,34 \\
\hline $\begin{array}{l}\text { Firmamız, ürün geliştirme } \\
\text { sürecinin ilk adımından } \\
\text { itibaren lider kullanıcıları bu } \\
\text { sürece dahil eder. }\end{array}$ & $\begin{array}{c}\mathrm{LK} \\
3\end{array}$ & & & 0,96 & 0,45 & 8,66 \\
\hline $\begin{array}{l}\text { Pazarımızdaki müşterilerin } \\
\text { yeni eğilimlerini öğrenmek } \\
\text { için lider kullanıcı yöntemini } \\
\text { kullanırız. }\end{array}$ & $\begin{array}{c}\mathrm{LK} \\
4\end{array}$ & & & 0,93 & 0,71 & 7,11 \\
\hline
\end{tabular}

Araştırma modelinde yer alan keşifsel inovasyon stratejisi, artırımsal inovasyon stratejisi ve firma performansı değişkenleri doğrulayıcı faktör analizi ile test edilmiştir. Keşifsel inovasyon stratejisi (7 ifade), artırımsal inovasyon stratejisi (10 ifade) ve firma performansını (6 ifade) ölçmek amacıyla oluşturulan ölçeklerden güvenilirlik analizi sonucunda kalan keşifsel inovasyon stratejisinden 7 ifade, artırımsal inovasyon stratejisinden 7 ifade ve firma performansından 6 ifade analize tabi tutulmuştur. Aşağıda Tablo 9'da modifikasyonlar sonrası ölçeklerin uyum değerleri verilmiştir. 
Tablo 9: İnovasyon Stratejileri ve Firma Performansı Ölçeklerinin Modifikasyonlar Sonrası Uyum Değerleri

\begin{tabular}{|c|c|c|c|c|}
\hline & $\begin{array}{c}\text { Uyumluluk } \\
\text { İndeksleri }\end{array}$ & $\begin{array}{l}\text { Ölçeğin } \\
\text { Uyum } \\
\text { Değerleri }\end{array}$ & $\begin{array}{c}\text { Mükemmel } \\
\text { Uyum Değerleri }\end{array}$ & $\begin{array}{c}\text { Kabul } \\
\text { Edilebilir } \\
\text { Uyum Değerleri }\end{array}$ \\
\hline \multirow{12}{*}{ 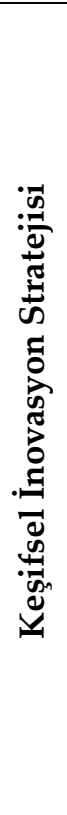 } & Ki-Kare $\left(\chi^{2}\right)$ & 5,14 & $0 \leq \chi^{2} \leq 2 \mathrm{df}$ & $2 \mathrm{df} \leq \chi^{2} \leq 3 \mathrm{df}$ \\
\hline & p değeri & 0,073 & $0,05<\mathrm{p} \leq 1,00$ & $0,01 \leq p \leq 0,05$ \\
\hline & $\begin{array}{l}\text { Serbestlik } \\
\text { derecesi (df) }\end{array}$ & 2 & & \\
\hline & $\chi^{2} / \mathrm{df}$ & 2,57 & $0 \leq \chi^{2} / \mathrm{df} \leq 2$ & $2 \leq \chi^{2} / \mathrm{df} \leq 3$ \\
\hline & RMSEA & 0,067 & $0 \leq$ RMSEA $\leq 0,05$ & $\begin{array}{c}0,05 \leq \text { RMSEA } \leq \\
0,08\end{array}$ \\
\hline & SRMR & 0,034 & $0 \leq \mathrm{SRMR} \leq 0,05$ & $\begin{array}{c}0,05 \leq \mathrm{SRMR} \leq \\
0,10\end{array}$ \\
\hline & NFI & 0,97 & $0,95 \leq \mathrm{NFI} \leq 1,00$ & $0,90 \leq \mathrm{NFI} \leq 0,95$ \\
\hline & NNFI & 0,96 & $0,97 \leq \mathrm{NNFI} \leq 1,00$ & $\begin{array}{c}0,95 \leq \mathrm{NNFI} \leq \\
0,97\end{array}$ \\
\hline & CFI & 0,98 & $0,97 \leq \mathrm{CFI} \leq 1,00$ & $0,95 \leq \mathrm{CFI} \leq 0,97$ \\
\hline & GFI & 0,94 & $0,95 \leq \mathrm{GFI} \leq 1,00$ & $0,90 \leq \mathrm{GFI} \leq 0,95$ \\
\hline & AGFI & 0,89 & $0,90 \leq \mathrm{AGFI} \leq 1,00$ & $\begin{array}{c}0,85 \leq \mathrm{AGFI} \leq \\
0,90\end{array}$ \\
\hline & IFI & 0,96 & $0,95 \leq \mathrm{IFI} \leq 1,00$ & $0,90 \leq \mathrm{IFI} \leq 0,95$ \\
\hline \multirow{12}{*}{ 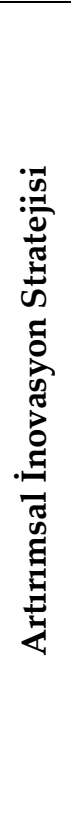 } & Ki-Kare $\left(\chi^{2}\right)$ & 7,89 & $0 \leq \chi^{2} \leq 2 \mathrm{df}$ & $2 \mathrm{df} \leq \chi^{2} \leq 3 \mathrm{df}$ \\
\hline & $p$ değeri & 0,067 & $0,05<p \leq 1,00$ & $0,01 \leq p \leq 0,05$ \\
\hline & $\begin{array}{l}\text { Serbestlik } \\
\text { derecesi (df) }\end{array}$ & 3 & & \\
\hline & $\chi^{2} / \mathrm{df}$ & 2,63 & $0 \leq \chi^{2} / \mathrm{df} \leq 2$ & $2 \leq \chi^{2} / \mathrm{df} \leq 3$ \\
\hline & RMSEA & 0,065 & $0 \leq \mathrm{RMSEA} \leq 0,05$ & $\begin{array}{c}0,05 \leq \text { RMSEA } \leq \\
0,08\end{array}$ \\
\hline & SRMR & 0,048 & $0 \leq \mathrm{SRMR} \leq 0,05$ & $\begin{array}{c}0,05 \leq \mathrm{SRMR} \leq \\
0,10\end{array}$ \\
\hline & NFI & 0,94 & $0,95 \leq \mathrm{NFI} \leq 1,00$ & $0,90 \leq \mathrm{NFI} \leq 0,95$ \\
\hline & NNFI & 0,96 & $0,97 \leq \mathrm{NNFI} \leq 1,00$ & $\begin{array}{c}0,95 \leq \mathrm{NNFI} \leq \\
0,97\end{array}$ \\
\hline & CFI & 0,96 & $0,97 \leq \mathrm{CFI} \leq 1,00$ & $0,95 \leq \mathrm{CFI} \leq 0,97$ \\
\hline & GFI & 0,98 & $0,95 \leq \mathrm{GFI} \leq 1,00$ & $0,90 \leq \mathrm{GFI} \leq 0,95$ \\
\hline & AGFI & 0,91 & $0,90 \leq \mathrm{AGFI} \leq 1,00$ & $\begin{array}{c}0,85 \leq \text { AGFI } \leq \\
0,90\end{array}$ \\
\hline & IFI & 0,96 & $0,95 \leq \mathrm{IFI} \leq 1,00$ & $0,90 \leq \mathrm{IFI} \leq 0,95$ \\
\hline
\end{tabular}




\begin{tabular}{|c|c|c|c|c|}
\hline \multirow{12}{*}{ 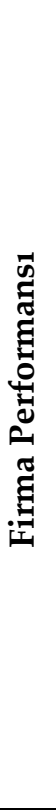 } & Ki-Kare $\left(\chi^{2}\right)$ & 6,78 & $0 \leq \chi^{2} \leq 2 \mathrm{df}$ & $2 \mathrm{df} \leq \chi^{2} \leq 3 \mathrm{df}$ \\
\hline & $\mathrm{p}$ değeri & 0,038 & $0,05<\mathrm{p} \leq 1,00$ & $0,01 \leq \mathrm{p} \leq 0,05$ \\
\hline & $\begin{array}{l}\text { Serbestlik } \\
\text { derecesi (df) }\end{array}$ & 3 & & \\
\hline & $\chi^{2} / \mathrm{df}$ & 2,26 & $0 \leq \chi^{2} / \mathrm{df} \leq 2$ & $2 \leq \chi^{2} / \mathrm{df} \leq 3$ \\
\hline & RMSEA & 0,072 & $0 \leq \mathrm{RMSEA} \leq 0,05$ & $\begin{array}{c}0,05 \leq \text { RMSEA } \leq \\
0,08\end{array}$ \\
\hline & SRMR & 0,054 & $0 \leq \mathrm{SRMR} \leq 0,05$ & $\begin{array}{c}0,05 \leq \mathrm{SRMR} \leq \\
0,10\end{array}$ \\
\hline & NFI & 0,92 & $0,95 \leq \mathrm{NFI} \leq 1,00$ & $0,90 \leq \mathrm{NFI} \leq 0,95$ \\
\hline & NNFI & 0,96 & $0,97 \leq \mathrm{NNFI} \leq 1,00$ & $\begin{array}{c}0,95 \leq \mathrm{NNFI} \leq \\
0,97\end{array}$ \\
\hline & CFI & 0,96 & $0,97 \leq \mathrm{CFI} \leq 1,00$ & $0,95 \leq \mathrm{CFI} \leq 0,97$ \\
\hline & GFI & 0,91 & $0,95 \leq \mathrm{GFI} \leq 1,00$ & $0,90 \leq \mathrm{GFI} \leq 0,95$ \\
\hline & AGFI & 0,86 & $0,90 \leq \mathrm{AGFI} \leq 1,00$ & $\begin{array}{c}0,85 \leq \mathrm{AGFI} \leq \\
0,90\end{array}$ \\
\hline & IFI & 0,90 & $0,95 \leq$ IFI $\leq 1,00$ & $0,90 \leq \mathrm{IFI} \leq 0,95$ \\
\hline
\end{tabular}

Keşifsel inovasyon stratejisi, artırımsal inovasyon stratejisi ve firma performansını oluşturan değişkenlerle ilgili yapılan modifikasyonlar sonrasında kalan değişkenlerin Cronbach's alfa değeri, standart katsayıları, $\mathrm{R}^{2}$, $\mathrm{t}$ değerleri, yapı güvenilirliği ve açıklanan varyans oranı aşağıdaki Tablo $10^{\prime}$ da gösterilmiştir.

Tablo 10: İnovasyon Stratejileri ve Firma Performansını Oluşturan Ölçeklerin Değişkenlerine Ait Değerler

\begin{tabular}{|l|l|l|l|l|l|l|}
\hline \multirow{2}{*}{$\begin{array}{l}\text { Keşifsel İnovasyon } \\
\text { Stratejisi }\end{array}$} & $\boldsymbol{\alpha}$ & $\mathbf{Y G}$ & $\begin{array}{l}\text { AVO } \\
\mathbf{( \% )}\end{array}$ & Standart \\
\cline { 2 - 7 } & $\mathbf{0 , 7 6}$ & $\mathbf{0 , 8 8}$ & $\mathbf{0 , 6 4}$ & $\mathbf{R}^{2}$ & $\begin{array}{l}\mathbf{t} \\
\text { değeri }\end{array}$ \\
\hline $\begin{array}{l}\text { Firmamı için pazara } \\
\text { yepyeni ürün icat edip } \\
\text { sunmak önemlidir. }\end{array}$ & KS1 & & & 0,90 & 0,82 & 14,76 \\
\hline $\begin{array}{l}\text { Yeni endüstri alanlarına } \\
\text { girmek bizim için önemlidir. }\end{array}$ & KS3 & & & 0,49 & 0,24 & 6,89 \\
\hline
\end{tabular}


Sosyal Bilimler Dergisi 49

\begin{tabular}{|c|c|c|c|c|c|c|}
\hline $\begin{array}{l}\text { Keşifsel inovasyon } \\
\text { firmamızın farklı birimleri } \\
\text { (Ar\&Ge, Pazarlama, üretim } \\
\text { birimleri vb.) tarafından } \\
\text { gerçekleştirilir. }\end{array}$ & KS4 & & & 0,73 & 0,54 & 11,17 \\
\hline $\begin{array}{l}\text { Birçok yeni ürün fikrini } \\
\text { başarıyla hayata geçiririz. }\end{array}$ & KS5 & & & 0,55 & 0,30 & 7,85 \\
\hline $\begin{array}{l}\text { Yeni ürünlerimiz pazarda } \\
\text { köklü } \text { değişimlere } \\
\text { (pazarlama, satış, üretim, } \\
\text { tedarik, vb. alanlarda) sebep } \\
\text { olur. }\end{array}$ & KS6 & & & 0,61 & 0,38 & 8,96 \\
\hline \multirow{2}{*}{$\begin{array}{l}\text { Artırımsal İnovasyon } \\
\text { Stratejisi }\end{array}$} & $\alpha$ & YG & $\begin{array}{c}\text { AVO } \\
(\%)\end{array}$ & \multirow{2}{*}{$\begin{array}{c}\text { Standart } \\
\text { Değer }\end{array}$} & \multirow{2}{*}{$\mathbf{R}^{2}$} & \multirow{2}{*}{$\begin{array}{c}t \\
\text { değeri }\end{array}$} \\
\hline & 0,76 & 0,80 & 0,51 & & & \\
\hline $\begin{array}{l}\text { Ürün geliştirmek için halen } \\
\text { kullanmakta olduğumuz } \\
\text { teknoloji ile } \text { yeni } \\
\text { teknolojinin birleşimi olan } \\
\text { teknolojik sistemi tercih } \\
\text { ederiz. }\end{array}$ & AS4 & & & 0,41 & 0,17 & 5,28 \\
\hline $\begin{array}{l}\text { Üretim esnekliğini } \\
\text { arttırmaya önem veririz. }\end{array}$ & AS5 & & & 0,36 & 0,13 & 4,56 \\
\hline $\begin{array}{l}\text { Verimi arttırmak temel } \\
\text { amacımızdır. }\end{array}$ & AS6 & & & 0,84 & 0,71 & 9,99 \\
\hline $\begin{array}{ll}\text { Var olan } & \text { ürünleri } \\
\text { gerektiğinde } & \text { yeniden } \\
\text { konumlandırırız. } & \\
\end{array}$ & AS8 & & & 0,72 & 0,52 & 8,86 \\
\hline \multirow{2}{*}{ Firma Performansı } & $\alpha$ & YG & $\begin{array}{c}\text { AVO } \\
(\%)\end{array}$ & \multirow{2}{*}{$\begin{array}{c}\text { Standart } \\
\text { Değer }\end{array}$} & \multirow{2}{*}{$\mathbf{R}^{2}$} & \multirow{2}{*}{$\begin{array}{c}t \\
\text { değeri }\end{array}$} \\
\hline & 0,76 & 0,80 & 0,51 & & & \\
\hline $\begin{array}{l}\text { Son } 5 \text { yılda rakiplerimize } \\
\text { göre satışlarımız artmıştır. }\end{array}$ & FP3 & & & 0,57 & 0,32 & 6,03 \\
\hline $\begin{array}{l}\text { Son } 5 \text { yılda rakiplerimize } \\
\text { göre satış kârlılığımız daha } \\
\text { iyidir. }\end{array}$ & FP4 & & & 0,45 & 0,20 & 5,00 \\
\hline
\end{tabular}




\begin{tabular}{|c|c|c|c|c|}
\hline $\begin{array}{l}\text { Son } 5 \text { yılda yeni ürünün } \\
\text { geliştirilmesi ile hedeflenen } \\
\text { kârlılık } \\
\text { ulașılmıștır. }\end{array}$ & FP5 & 0,66 & 0,44 & 6,64 \\
\hline $\begin{array}{l}\text { Son } 5 \text { yılda rakiplerimiz ile } \\
\text { kıyasladığımızda } \\
\text { yatırımlarımızın } \\
\text { dönüşü daha fazladır. }\end{array}$ & FP6 & 0,65 & 0,12 & 6,61 \\
\hline
\end{tabular}

\section{Araştırma Modelinin Test Edilmesi}

Müşteri ilişkileri yönetiminin inovasyon stratejilerine etkisini belirlemek üzere geliştirilen araştırma modelini test etmek amaciyla Path analizi yapılmıştır. Modelde yer alan rakipler ile kıyaslama, müşteri bilgi süreci, lider kullanıcılar ile işbirliği değişkenlerinin ara (keşifsel ve artırımsal inovasyon stratejileri) değişkenler üzerindeki, ara değişkenlerinde çıktı (firma performansı) değişkeni üzerindeki etkisi incelenmiştir.

Analiz sonucunda elde edilen ilk bulgular doğrultusunda, müşteri bilgi sürecinin inovasyon stratejileri üzerinde doğrudan veya dolaylı anlamlı bir etkide bulunmadığı tespit edilmiştir. Müşteri bilgi süreci ile modifikasyon öneren değişkenler modelden çıkarıldıktan sonra elde edilen modelin uyum değerleri Tablo $11^{\prime}$ de gösterilmiştir. 
Sosyal Bilimler Dergisi 51

Tablo 11: Araştırma Modelinin Uyum Değerleri

\begin{tabular}{|c|c|c|c|c|}
\hline $\begin{array}{c}\text { Uyumlulu } \\
\text { k } \\
\text { İndeksleri }\end{array}$ & $\begin{array}{c}\text { Modifikasyo } \\
\text { n Öncesi } \\
\text { Değerler }\end{array}$ & $\begin{array}{c}\text { Modifikasyo } \\
\text { n Sonrası } \\
\text { Değerler }\end{array}$ & $\begin{array}{c}\text { Mükemmel } \\
\text { Uyum } \\
\text { Değerleri }\end{array}$ & $\begin{array}{c}\text { Kabul } \\
\text { Edilebilir } \\
\text { Uyum } \\
\text { Değerleri }\end{array}$ \\
\hline $\begin{array}{l}\text { Ki-Kare } \\
\left(\chi^{2}\right)\end{array}$ & 9721,43 & 2947,37 & $0 \leq \chi^{2} \leq 2 \mathrm{df}$ & $2 \mathrm{df} \leq \chi^{2} \leq 3 \mathrm{df}$ \\
\hline p değeri & 0,000 & 0,000 & $0,05<p \leq 1,00$ & $0,01 \leq p \leq 0,05$ \\
\hline $\begin{array}{l}\text { Serbestlik } \\
\text { derecesi } \\
\text { (df) }\end{array}$ & 2140 & 1405 & & \\
\hline$\chi^{2 / d f}$ & 4,54 & 2,09 & $0 \leq \chi^{2} / \mathrm{df} \leq 2$ & $2 \leq \chi^{2} / \mathrm{df} \leq 3$ \\
\hline RMSEA & 0,090 & 0,064 & $\begin{array}{c}0 \leq \mathrm{RMSEA} \leq \\
0,05\end{array}$ & $\begin{array}{c}0,05 \leq \\
\text { RMSEA } \leq 0,08\end{array}$ \\
\hline SRMR & 0,11 & 0,028 & $0 \leq \mathrm{SRMR} \leq 0,05$ & $\begin{array}{c}0,05 \leq \mathrm{SRMR} \leq 0 \\
10\end{array}$ \\
\hline NFI & 0,78 & 0,93 & $\begin{array}{c}0,95 \leq \mathrm{NFI} \leq \\
1,00\end{array}$ & $0,90 \leq \mathrm{NFI} \leq 0,95$ \\
\hline NNFI & 0,86 & 0,97 & $\begin{array}{c}0,97 \leq \mathrm{NNFI} \leq 1 \\
00\end{array}$ & $\begin{array}{c}0,95 \leq \mathrm{NNFI} \leq 0,9 \\
7\end{array}$ \\
\hline CFI & 0,79 & 0,98 & $0,97 \leq \mathrm{CFI} \leq 1,00$ & $0,95 \leq \mathrm{CFI} \leq 0,97$ \\
\hline GFI & 0,61 & 0,97 & $0,95 \leq \mathrm{GFI} \leq 1,00$ & $0,90 \leq \mathrm{GFI} \leq 0,95$ \\
\hline AGFI & 0,72 & 0,91 & $\begin{array}{c}0,90 \leq \mathrm{AGFI} \leq 1 \\
00\end{array}$ & $\begin{array}{c}0,85 \leq \mathrm{AGFI} \leq 0,9 \\
0\end{array}$ \\
\hline IFI & 0,71 & 0,96 & $0,95 \leq \mathrm{IFI} \leq 1,00$ & $0,90 \leq \mathrm{IFI} \leq 0,95$ \\
\hline
\end{tabular}

Yukarıdaki tabloda ölçeğin kabul edilmesi için kullanılan istatistiksel uyum indeksleri gösterilmektedir. Modifikasyon sonrasında $\chi^{2}$ / df oranı 2,09 ve Yaklaşık Hataların Ortalama Kare Kökü (RMSEA) değeri 0,0,064 olup kabul edilebilir uyum değerleri arasında yer almıştır. Standartlaştırılmış Ortalama Hataların Kare Kökü (SRMR) 0,028 değeri ile mükemmel uyum değerleri arasındadır. Normlaştırılmış ve Normlaştırılmamış (NFI ve NNFI) Uyum İndeksleri sırasıyla 0,93 ve 0,97 değer ile kabul edilebilir uyum aralığındadır. Karşılaştırmalı Uyum İndeksi (CFI) 0,98 değeri ile mükemmel uyum düzeyindedir. Uyum İyiliği İndeksi (GFI) ve Düzeltilmiş Uyum İyiliği İndeksi (AGFI) 0,97 ve 0,91 değerlerini alarak mükemmel uyum değerlerine sahiptirler. Artırımlı Uyum İyiliği İndeksi (IFI) 0,96 değer ile mükemmel uyum düzeyindedir. Tüm uyum 
değerleri bir arada değerlendirildiğinde veri ve model arasındaki uyumun olduğu diğer bir ifadeyle test edilen ölçeğin geçerli olduğu söylenebilir.

Araştırmanın amacı doğrultusunda kurulan hipotezlere ilişkin sonuçlar aşağıdaki Tablo 12 'de gösterilmiştir.

Tablo 12: Hipotez Testi Sonuçları

\begin{tabular}{|l|l|}
\hline Hipotezler & Sonuç \\
\hline $\begin{array}{l}\text { H1a: Rakipler ile kıyaslama keşifsel inovasyon stratejisini } \\
\text { etkilemektedir. }\end{array}$ & KABUL \\
\hline $\begin{array}{l}\text { H1b: Müşteri bilgi süreci keşifsel inovasyon stratejisini } \\
\text { etkilemektedir. }\end{array}$ & RED \\
\hline $\begin{array}{l}\text { H1c: Lider kullanıcılarla işbirliği keşifsel inovasyon stratejisini } \\
\text { etkilemektedir. }\end{array}$ & RED \\
\hline $\begin{array}{l}\text { H1d: Rakipler ile kıyaslama artırımsal inovasyon stratejisini } \\
\text { etkilemektedir. }\end{array}$ & KABUL \\
\hline $\begin{array}{l}\text { H1e: Müşteri bilgi süreci artırımsal inovasyon stratejisini } \\
\text { etkilemektedir. }\end{array}$ & RED \\
\hline $\begin{array}{l}\text { H1f: Lider kullanıcılarla işbirliği artırımsal inovasyon stratejisi } \\
\text { etkilemektedir. }\end{array}$ & KABUL \\
\hline $\begin{array}{l}\text { H2a: Keşifsel inovasyon stratejisi firma performansını } \\
\text { etkilemektedir. }\end{array}$ & KABUL \\
\hline $\begin{array}{l}\text { H2b: Artırımsal inovasyon stratejisi firma performansını } \\
\text { etkilemektedir. }\end{array}$ & KABUL \\
\hline
\end{tabular}

Tablo 12'de görüldüğü üzere müşteri bilgi süreci ve lider kullanıcılar ile işbirliğinin keşifsel inovasyon stratejisini etkilediğini ileri süren hipotezler $(\mathrm{H} 1 \mathrm{~b}, \mathrm{H} 1 \mathrm{c})$ reddedilmiştir. Benzer şekilde müşteri bilgi sürecinin artırımsal inovasyon stratejisini etkilediğini ileri süren hipotezler (H1e) reddedilmiştir.

Rakipler ile kıyaslamanın keşifsel inovasyon stratejisini etkilediğini ileri süren H1a hipotezi kabul edilmiştir. Artırımsal inovasyon stratejisini etkilediği ileri sürülen rakipler ile kıyaslama hipotezi (H1d) kabul edilmiştir. İnovasyon stratejilerinin firma performansını etkilediğini ileri süren $\mathrm{H} 2 \mathrm{a}$ ve $\mathrm{H} 2 \mathrm{~b}$ hipotezleri de kabul edilmiştir. Araştırma sonucunda elde edilen inovasyon stratejileri modelindeki tüm değişkenlerin standart ve $\mathrm{R}^{2}$ değerleri Şekil 2' de gösterilmektedir. 


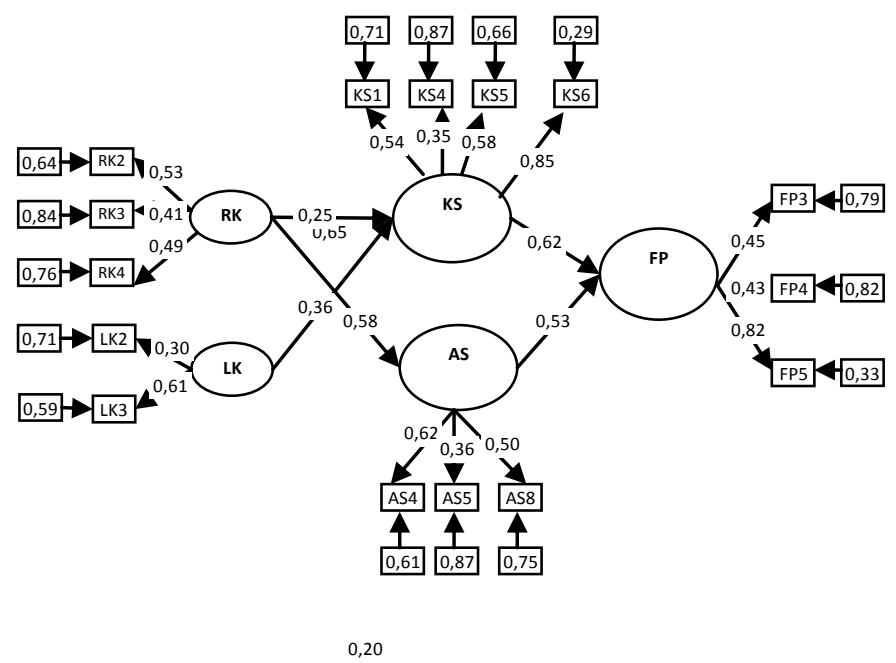

Şekil 2: Araştırma Modelinin Tahmini ve Standart Değerleri

\section{Sonuç ve Öneriler}

Müşteri ilişkileri yönetiminin keşifsel ve artırımsal stratejilere ve bunların firma performansı üzerindeki etkilerinin incelendiği bu çalışmada aşağıda sıralanan sonuçlar elde edilmiştir.

Cevaplayıcların ve firmaları özellikleri ile ilgili bulgular:

Sonuçlardan anlaşıldığı gibi cevaplayıcılar; çoğunlukla 41-45 yaş grubunda, 15-19 yıl arasında firmada çalışan, pazarlama müdürü, üniversite mezunu ve erkeklerden oluşmaktadır. Araştırmaya katılan firmalar, 5001999 arası çalışanı olan, 25-49 yıl arası faaliyet gösteren, büyük çoğunluğu yerli sermaye yapısında ve Ar\&Ge bölümüne sahiptir. Bu bağlamda, 2 ürün icat eden, 6 ve daha fazla sayıda ürün geliştiren ve 2 ürünün patentine sahiptirler.

Cevaplayıcıların müşteri ilişkileri yönetimine yönelik algı ve düşüncelerine ilişkin bulgular:

Cevaplayıcıların, rakipler ile kendilerini kıyaslamaya yönelik algı düzeyleri yüksektir. Firmalar, rakiplerin ürün stratejileri hakkında düzenli olarak araştırma yaptıklarını ifade etmektedirler. Ayrıca, sürekli olarak rakiplerin sahip olduğu yeni ürünlerin neler olduğunu araştırmaktadırlar. Ancak cevaplayıcılar, rakiplerinin sürekli değiştirmediklerini düşünmektedirler.

Firmaların, müşteri bilgi sürecine yönelik algıları yüksektir. Cevaplayıcılar, yeni ürün tasarımı esnasında müşterilerden gelen eleştiri ve önerilerin önemli olduğunu düşünmektedirler. Ayrıca, düzenli olarak 
müşteri bilgilerini analiz etmektedirler. Firmalar, yeni ürün fikirleri için düzenli olarak müşterilerin fikirlerine başvurduklarını ifade etmektedirler. Müşterilerin ürün tercihlerinin sürekli değiştiğini düşünmektedirler.

Cevaplayıcıların, lider kullanıcı yöntemine yönelik algı düzeyleri yüksektir. Firmalar, ürünlerinin fonksiyonlarını değerlendirebilen müşterilerini bilmek istediklerini belirtmişlerdir. Ayrıca, ürün geliştirme sürecinin ilk adımından itibaren lider kullanıcıları bu sürece dahil etmektedirler.

Cevaplayıcılarm inovasyon stratejilerine yönelik algı ve düşüncelerine ilişkin bulgular:

Firmaların, keşifsel inovasyon stratejisine yönelik alg1 ve düşüncelerinin ortalaması 3,714'dür. Cevaplayıcılar, keşifsel inovasyon stratejilerinin firmanın Ar\&Ge, pazarlama, üretim vb. farklı birimleri tarafından gerçekleştirildiğini ifade etmekte ve bu stratejilerin uygulanması sonucunda oluşturulan yeni ürünlerin pazarlama, satış, üretim, tedarik vb. alanlarda köklü değişimlere sebep olduğuna inanmaktadırlar. Ancak, bu stratejilerin uygulanmasının var olan üründe köklü değişiklik yaptığına yönelik düşünceleri çok olumlu değildir.

Cevaplayıcıların artırımsal inovasyon stratejilerinin uygulamasına yönelik alg1 ve düşünceleri oldukça yüksektir. Firmalar, verimliliğin ve üretim esnekliğinin arttırılmasını düşünmektedirler. Bu bağlamda, hammadde tüketimini azaltmak için sürekli araştırma yaptıklarını ifade etmektedirler. Yeni ürün geliştirmede mevcut teknoloji ile yeni teknolojiyi birleştirmenin daha uygun olacağını düşünmektedirler.

Cevaplayıcıların firma performansına yönelik algı ve düşüncelerine ilişkin bulgular:

Cevaplayıcıların firma performansı ifadelerine yönelik algıları yüksektir. Firmalar, son 5 yılda rakipleriyle kıyaslandığında satış kârlılıklarının daha iyi, yatırımların geri dönüşünün daha fazla ve yeni ürün geliştirme için yaptıkları yatırımların getirisinin daha yüksek olduğunu ifade etmektedirler. Ayrıca, son yıllarda satışlarının arttığını düşünmektedirler.

Müşteri ilişkileri yönetiminin inovasyon stratejileri üzerindeki etkilerine ilişkin elde edilen bulgular:

Müşteri ilişkileri yönetimini, rakipler ile kıyaslama, müşteri bilgi süreci ve lider kullanıcılar ile işbirliği oluşturmaktadır. Araştırma sonuçlarına göre kıyaslama ve lider kullanıcılar inovasyon stratejilerini etkilemekle birlikte müşteri bilgi sürecinin etkisi bulunmamaktadır. Rakipler 
ile kıyaslama yapılması keşifsel ve artırımsal stratejileri etkilerken lider kullanıcılar ile işbirliği sadece artırımsal stratejileri etkilemektedir.

Rakiplerin sahip olduğu yeni ürünler, firmaların ürün stratejilerini etkilemektedir. $\mathrm{Bu}$ durum firmaları, rakiplerinin ürün stratejilerini araştırmasına ve müşterilerinin onlardan satın aldıklarını sürekli olarak takip etmesine neden olmaktadır. Bu ise, birçok yeni ürün fikrinin başarıyla uygulanmasını sağlamakta ve sonucunda üretim sistemlerinin etkin ve verimli şekilde düzenlenmesine yardımcı olmaktadır.

İnovasyon geliştirme sürecine lider kullanıcıların başlangıçtan itibaren dahil edilmesi, müşteri istek ve ihtiyaçlarının öğrenilmesine ve bunlara daha iyi çözüm önerilerinin geliştirilmesine yardımcı olmaktadır. Lider kullanıcıların gerçek yaşam tecrübelerinin kullanılması, ihtiyaçları karşılamak için ya yepyeni ürünlerin oluşturulmasını yada var olan ürünlerde değişiklikler yapılmasını gerektirmektedir. Lider kullanıcılar, ihtiyaçlara çözüm elde etmek için firmanın bütün bölümleriyle birlikte çalışmaktadırlar. Bu birlikte çalışma sonucunda ortaya çıkan ürün firmanın rekabet gücüne olumlu katkı sağlamaktadır.

İnovasyon stratejilerinin firma performansı üzerindeki etkilerine ilişkin elde edilen bulgular:

Firma performansı kârlılık, satışlardaki büyüme, yatırımların geri dönüşü ve pazar payı gibi objektif ölçütlerle olduğu gibi müşteri memnuniyeti, çalışan memnuniyeti gibi kişisel kanaatlere dayanan subjektif ölçütlerle de ölçülebilmektedir (Dess ve Robinson, 2004). Firma performansını ölçerken kullanılan diğer bir yöntem, rakiplere ya da sektör ortalamalasına göre kıyaslamaların yapıldığı ölçeklerin kullanılmasıdır (Despande ve arkadaşları, 2003; Jaworski ve Kohli, 1993). Bu ölçeklerde performans, satışlar, kârlılık, müşteri tatmini gibi açlardan sektör ya da rakiplere göre kıyaslanarak değerlendirilmektedir. Diğer bazı çalışmalarda da işletme performansı ölçümünde farklı göstergeler kullanılmıştır. Venkatraman ve Ramanujam $(1986,1987)$ performans ölçümü ile ilgili yaptıkları çalışmada işletme performansının ölçümünde finansal unsurların yanı sıra teknik performans, inovasyon performansı gibi finansal olmayan verilere dayanan ölçüm yöntemleri de kullanılmaktadır. Bu araştırmada objektif kriterlere göre belirlenen performans ölçüm tekniği kullanılmıştır.

Bu çalışmada, keşifsel ve artırımsal inovasyon stratejilerinin firma performansını etkilediği tespit edilmiştir. Yepyeni ürün icat edilmesi ve bunların pazara sunulması firmaların hedefledikleri kârlılık rakamlarına ulaşmalarına yardımcı olmaktadır. Ayrıca Üretim, tedarik, pazarlama ve satış vb. köklü değişimlere sebep olacak yeni ürünlere sahip olan firmaların satış kârlılıkları rakiplerine göre daha iyi olmaktadır. Üretim esnekliğine 
önem verilmesi ve bu bağlamda mevcut ürünlerin başka pazar bölümlerinde yeniden konulandırılması satışları artırmaktadır.

Yönetimsel Bulgular:

$\mathrm{Bu}$ araştırmada, müşteri ilişkileri yönetiminin inovasyon stratejilerine etkisi test edilmiştir. Pazarlamada inovasyonun öneminin artmasının sebepleri arasında sınırların kalkması, müşteri beklentilerinin artması ve değişimin hızlı olması sıralanabilir. Bu değişimler müşterileri için daha fazla ve ihtiyaçlara en uygun değerler üretmeyi gerektirir. Ancak bu değerlerin sürdürülebilir ve rekabetçi olabilmesi için rakiplerin sunmuş olduğu değerlerden daha iyi, hızlı ve taklit edilme ihtimalinin düşük olması gerekir.

Müşteri odaklı hale gelen firmalar, müşteriler için değer yaratan çözümleri bulmaya önem verirler. Bunların; ürünleri, hizmetleri ve süreçleri, müşterinin kalite ve tatmin beklentisine uygun şekilde farklılaştırmaları gerekir. Bu farklılaştırmayı sağlamak için gerekli olan ise inovasyondur. Müşteri ilişkileri faliyetlerinde inovasyon kavramı ve anlayışı odak noktaya yerleştirilmelidir. Çünkü inovasyon sayesinde, müşteri isteklerini etkin ve verimli şekilde karşılayabilme yeteneği kazanılmaktadır.

Müşteri ilişkilerinde kıyaslamaya ve lider kullanıcılara önem verilmelidir. Kıyaslama, firmanın mevcut performansının düzenli ve sistematik olarak incelenmesini, rakiplerden farklı olan uygulamaların belirlenmesini sağlayabilir. Pazar payı ve kârlılığın artırılması, verimliliğin yükseltilmesi, kalitenin geliştirilmesi ve sonuçta müşteri memnuniyetinin sağlanabilmesinde kıyaslama yararlı olabilir.

Lider kullanıcılar, pazarda tüketici ihtiyaçlarını daha önceden bilir ve algılarlar. Bu ihtiyaçları karşılayacak çözüm önerilerini geliştirmede önemli fayda sağlarlar. Dolayısıyla, tüketici ihtiyaçlarını önceden sezebilen bu müşterileri ürün geliştirme sürecinin aşamalarına dâhil eden firmalar, belirgin ve açık olmayan müşteri ihtiyaçlarını tanımlayabilir. Lider kullanıcılarla ürün kavramı oluşturabilir. Tüketici ihtiyaçlarının tespiti için, geleneksel pazar araştırması yöntemleriyle harcanan zamanı kısaltarak ürün geliştirme çalışmalarının maliyetini azaltabilir. $\mathrm{Bu}$ yüzden lider kullanıcıların ürün geliştirme süreci aşamalarına dâhil edilmesi ürün geliştirme performansının artırılmasına ve çevirim zamanının kısaltılmasına önemli katkı sağlayacaktır.

İnovasyon stratejilerinin en önemlisi teknolojiye dayalı olarak bilinen "keşifsel inovasyon stratejisi" dir. Bu tür stratejiyi izleyen firmaların pazara sürekli yeni ürünler sunan, iş yapış yöntemlerini müşteri-odaklı 
biçimde düzenleyen ve sektördeki gelişmeleri çok iyi takip eden firmalar oldukları görülmektedir. Ayrıca, bu tür firmaların, güçlü bir bilgi birikimine sahip olması, çalışanların ve üst düzey yöneticilerin inovasyona ve risk almaktan korkmaması, firma içi ilişkilerin ve iletişimin optimal düzeyde olması, organizasyon yapısının esnek ve öğrenen nitelik taşıması gerekmektedir. Bunları gerçekleştiren firmaların inovasyon üretim oranları oldukça yüksek olması beklenmektedir.

Araştırmada kullanılan inovasyon stratejilerinden bir diğer strateji ise "artırımsal inovasyon stratejisi"dir. Bu stratejiyi izleyen işletmeler düşük işgücü, malzeme, enerji ve yatırım maliyetleri ile çalışırlar. Bu firmaların pazardaki başarı şansı geliştirdikleri ürünlerin sayısına bağlıdır. Bu sebepten, bu stratejiyi benimseyen firmaların pazardaki değişimlerle ilgili bilgi elde etmesinin kolaylaştırılması, geliştirilecek ürünün seçiminin uygun yapılması ve know-how alınacak firmaların belirlenmesi gerekmektedir.

Firmaların inovasyon yetenekleri onların örgüt kültürlerinin yenilikçi olup olmadığına bağlıdır. İnovasyonun sürdürülebilirliğini firmaların inovatif örgüt kültürleri ve yapıları belirlemektedir. Firmalarda inovasyon anlayışının oluşması için çalışanların yenilikçi özelliklerinin geliştirilmesi ve örgütün öğrenen yapıda olması gerekmektedir. Yeniden yapılanan bir firmada inovasyon faaliyetlerinin kolay şekilde kabullenilmesi için örgütün öğrenme yeteneğinin geliştirilmesi ve inovatif örgüt kültürünün geliştirilmesi gereklidir.

İnovasyon bilgi temeline dayanan; bilgilerin üretilmesine, paylaşılmasına yorumlanmasına ve bu doğrultuda bir takım yeni şeylerin oluşturulmasına bağlı olan bir süreçtir. Bu yönüyle bilgi temeline dayalı örgütsel öğrenme, pazar odaklılık, iletişim ve iş modelleri gibi yaklaşımlar ve uygulamalar inovasyonun gerçekleştirilmesine ve firma yapısının daha inovatif özelliğe kavuşmasına önemli katkılarda bulunacaktır.

Öneriler:

İnovasyon kavramı, günümüz firmaları için sürdürülebilir rekabetin temel dinamiklerinden birisi haline gelmiştir. Ancak organizasyon ve pazarlama alanlarında inovasyon yapabilmek ise inovatif örgüt kültürüne sahip olmakla mümkün olabilmektedir. Dolayısıyla inovatif örgüt kültürünün oluşturulmasının ve buna paralel olarak kültürel faktörlerin firmanın organizasyon yapısı ve pazarlama süreçlerinin inovasyon stratejileri üzerinde nasıl bir etkiye sahip olduğunun bilinmesi de oldukça önemlidir.

Özellikle icat gibi kavramlarla karıştırılan inovasyon için önemli ölçüde araştırma yapılması gibi yanlış inanışlar mevcuttur. Bunun gibi sebeplerle sadece büyük firmaların yapabileceği çalışmalar olarak görülen 
inovasyon konusuna küçük firmaların yeterince önem vermesi için işbirliğinin sağlanması yararlı olacaktır. Bu işbirliği ve bilgi paylaşımı seviyesini artırmak için

Bölgesel firmaların inovasyon yeteneğini arttırılabilmesi için büyük firmalar ile aralarındaki işbirliğinin temel ticari ilişkilerin ötesine geçmesi gerekmektedir. Ortak AR-GE, ortak ürün geliştirme, bilgi paylaşımı, deneyimlerin paylaşımı gibi konularda da işbirliği yapılması gerekmektedir. Yerel ve bölgesel kuruluşlar, bu tür işbirliklerini arttırıcı uygulamaları hayata geçirmelidirler.

Bilimsel ve teknik bilginin kaynağı olan üniversite ile firmalar arasındaki işbirliği arttırılmalıdır. Üniversitelerin yapmış olduğu çalışmaları, araştırmaları, teknik olanakları, laboratuar imkânlarını ve eğitim kalitesi ve öğretim elemanlarının uzmanlıkları gibi konularda

Sanayi odalarına gereken bilgi paylaşımını yapması yararlı olacaktır. $\mathrm{Bu}$ bağlamda, tarafları birleştirecek birtakım uygulamaların hayata geçirilmesi ya da zaten olan bu uygulamaların (Teknokent gibi) etkinliğinin arttırılması firmaların inovasyon yeteneklerinin artmasına yardımc olacaktır. Ayrıca firmaları bilgilendirici koordinatörlüklerin veya danışma ofislerinin hayata geçirilmesi, "nereye müracaat edileceğini bilmeyen" firmaların üniversiteden etkin bir şekilde faydalanabilmesini mümkün kılabilecektir. Bir diğer önemli sorun; sanayi kesimi ile üniversitenin üstünlüklerinin kesiștiği alanların tanımlanmamış olmasıdır. Bu çerçevede, her iki kesimin temsilcilerinin "ne yapılabileceği" konusunda daha sistematik ilişki kurmaları gerekmektedir. Ayrıca üniversite ve firmaların bir araya gelmesini sağlayacak dernek, vakıf, mesleki örgüt, tartışma, toplantı gibi etkinliklerin arttırılması ve firmalar ile yerel ve bölgesel aktörlerin düzenli olarak bir araya gelmesi sağlanmalıdır.

Karşılıklı güven inovasyonda önemli bir basamak olarak görülmektedir. Karşılıklı güven yaratılmadıkça pazarda inovasyonu mümkün kılan işbirlikçi yapı ortaya çıkamayacaktır. Politika yapıcılar güven ortamının inşasında daha aktif olmalı ve tarafların birbirine olan güven düzeyinin arttırılmasının yeni yollarını aramalıdır. Bu amaç için ulusal inovasyon sistemi kurulmalıdır. Bu sistem için gerekli olan toplumsal farkındalığın ve inovasyon kültürünün oluşmasında, yasal düzenlemelerin yapılmasında ve inovasyon için gerekli olan finansmanın sağlanmasında yasal otoritenin aktif katılımının sağlanması inovasyonun etkinliğini artıracaktır. 
Sosyal Bilimler Dergisi 59

\section{Kaynakça}

ALEGRE, J., LAPIEDRA, R., ve CHIVA, R. (2006). “A Measurement Scale for Product Innovation Performance". European Journal of Innovation Management, 9(4), 333-346.

ARTTO, K., MARTINSUO, M., DIETRICH, P. ve KUJALA, J. (2008). “Project Strategy: Strategy Types and Their Contents in Innovation Projects". International Journal of Managing Projects in Business, 1(1), 49-70.

ATUAHENE-GIMA, K. ve WEI, Y. (2011). "The Vital Role of ProblemSolving Competence in New Product Success". Journal of Product Innovation Management, 28(1), 81-98.

BENNER, M.J. (2009). “Dynamic or Static Capabilities? Process Management Practices and Response to Technological Change". Journal of Product Innovation Management, 26(5), 473-486.

BEVERLAND, M.B., NAPOLI, J. ve FARRELLY, F. (2010). “Can All Brands Innovate in the Same Way? A Typology of Brand Position and Innovation Effort". Journal of Product Innovation Management, 27(1), 33-48.

BHASKARAN, S. (2006). "Incremental Innovation and Business Performance: Small and Medium-Size Food Enterprises in a Concentrated Industry Environment". Journal of Small Business Management, 44(1), 64-80.

BOSSO, J.A., CHISHOLM-BURNS, M., NAPPI, J., GUBBINS, P.O. ve ROSS, L.A. (2010). "Benchmarking in Academic Pharmacy Departments". American Journal of Pharmaceutical Education, 74(8), 1-7.

CAMBRA-FIERRO, J.J., HART, S., MUR, A.F. ve REDONDO, Y.P. (2011). "Looking for Performance: How Innovation and Strategy May Affect Market Orientation Models". Innovation: Management, policy \& practice, $13,154-172$.

CARPINETTI, L.C.R. ve DE MELO, A.M. (2002). "What to Benchmark? A Systematic Approach and Cases", Benchmarking: An International Journal, 9(3), 244-255.

CERDAN, A.L.M., ACOSTA, P.S. ve NICOLAS, C.L. (2008). "How Do Collaborative Technologies Affect Innovation in SMEs?". International Journal of e-Collaboration, 4(4), 33-50.

CHENG, C. ve SHIU, E. (2007). "Re-Innovation: The Redefined Definition". Journal of American Academy of Business, 11(1), 231-236.

COYNE, W. (2000). "Lead User: A Conversation with William Coyne". Health Forum Journal, 43(4), $28-29$. 
CUTHILL, I.D.H. (2001). Organizational Learning and New Product Development Success. (Ph.D.). Syracuse University.

DATTAKUMAR, R. ve JAGADEESH, R. (2003). “A Review of Literature on Benchmarking". Benchmarking, 10(3), 176-209.

DOĞAN, S. ve KILIÇ, S. (2008). "İlişki Yönetiminde İç ve Dış Müşteri Memnuniyetinin Sağlanması". Karamanoğlu Mehmetbey Üniversitesi İ̈BF Dergisi, 10(14), 60-87.

DURNA, U. (2002). Yenilik Yönetimi. Ankara:Nobel Yayın Dağıtım.

EICHORN, F.L. (2004). "Internal Customer Relationship Management (IntCRM) A Framework for Achieving Customer Relationship Management from the Inside Out". Problems and Perspectives in Management, 1, 154177.

FRANKE, N., VON HIPPEL, E. ve SCHREIER, M. (2006). “Finding Commercially Attractive User Innovations: A Test of Lead-User Theory". Journal of Product Innovation Management, 23(4), 301315.

FREDERICKS E. (2002). Is Co-Location Of New Product Development Teams Necessary. (Ph.D.). Chicago:University of Illinois.

FREEMAN, C. ve SOETE, L. (2004). Yenilik İktisadı (5. Basım). Ankara:TÜBITAK Yayınları.

GATIGNON, H. ve XUEREB, J-M. (1997). "Strategic Orientation of the Firm and New Product Performance". Journal of Marketing Research, 34(1), 77-90.

GRABHER, G., IBERT, O. ve FLOHR, S. (2008). "The Neglected King: The Customer in the New Knowledge Ecology of Innovation". Economic Geography, 84(3), 253-280.

GRESHAM, G.G. (2005). The Role of Interfunctional Market Orientation In New Product Program Success:A Exploratory Empirical Analysis. (Ph.D.). Old Dominion University.

HAN, J.K., KIM, N. ve KIM, H.B. (2001). “Entry Barriers: A Dull-, One-, or Two-Edged Sword for Incumbents? Unraveling The Paradox from a Contingency Perspective". Journal of Marketing, 65, 1-15.

HANVANICH, S., DROGE, C. ve CALATONE, R. (2003). "Reconceptualizing the Meaning and Domain of Marketing Knowledge". Journal of Knowledge Management, 7(4), 124-135.

HE, Z. ve WONG, P. (2004). "Exploration vs. Exploitation: An Empirical Test of The Ambidexterity Hypothesis". Organization Science, 15, 481-494. 
HENARD, D.H. ve DACIN, P.A. (2010). “Reputation for Product Innovation: Its Impact on Consumers". Journal of Product Innovation Management, 27(3), 321-335.

HENDERSON, A.D. (1999). "Firm Strategy and Age Dependence: A Contingent View of Liabilities of Newness, Adolescence and Obsolescence". Administrative Science Quarterly, 44, 281-314.

INTRACHOOTO, S. (2004). "Lead Users Concept in Building Design: Its Applicability to Member Selection in Technologically Innovative Projects". TQM Magazine, 16(5), 359-68.

İRAZ, R. (2005). Yaratıcılık ve Yenilik Bağlamında Girişimcilik ve KOBI'ler. Konya:Çizgi Kitabevi.

JAYACHANDRAN, S., HEWETT, K. VE KAUFMAN, P. (2004). “Customer Response Capability in a Sense-and-Respond Era: The Role of Customer Knowledge Process". Journal of Academy of Marketing Science. 32(3), 219-233.

KATILA, R. ve AHUJA, G. (2002). "Something Old, Something New: A Longitudinal Study of Search Behavior and New Product Introduction". Academy of Management Journal, 45, 1183-1194.

KEIZER, J.A. ve HAMLAN, J.I.M. (2007). "Diagnosing Risk In Radical Innovation Projects". Research-Technology Management, September, 30-36.

KIM, N. ve ATUAHENE-GIMA, K. (2010). "Using Exploratory and Exploitative Market Learning for New Product Development". Journal of Product Innovation Management, 27(4), 519-536.

KNUDSEN, M.P. (2007). "The Relative Importance of Interfirm Relationships and Knowledge Transfer for New Product Development Success". Journal Of Product Innovation Management, 24(1), 117-138.

KOLLER, M. ve SALZBERGER, T. (2009). "Benchmarking in Service Marketing- a Longitudinal Analysis of The Customer". Benchmarking: An International Journal, 16(3), 401-414.

KYRÖ, P. (2004). "Benchmarking As an Action Research Process". Benchmarking: An International Journal, 11(1), 52-73.

LAGROSEN, S. (2005). "Customer Involvement in New Product Development: Relationship Marketing Perspective". European Journal of Innovation Management, 8(4), 424-438.

LAVIE D. ve ROSENKOPF L. (2006). "Balancing Exploration and Exploitation in Alliance Formation". Academy Management of Journal, 49(4), 797-818. 
LAWSON, B., PETERSEN, K.J., COUSINS, P.D. ve HANDFIELD, R.B. (2009). "Knowledge Sharing in Interorganizational Product Development Teams: The Effect of Formal and Informal Socialization Mechanisms". Journal of Product Innovation Management, 26(2), 156-172.

LEDWITH, A. VE O'DWYER, M. (2009). "Market Orientation, NPD Performance, and Organizational Performance in Small Firms". Journal of Product Innovation Management, 26(6), 652-661.

LI, T. ve CALANTONE, R. (1998). “The Impact of Market Knowledge Competence on New Product Advantage: Conceptualization and Empirical Examination". Journal of Marketing, 62, 13-29.

LI, J., MERENDA, M. ve VENKATACHALAM, A.R. (2009). "Business Process Digitalization and New Product Development:An Empirical Study of Small and Medium-Sized Manufacturers". International Journal of E-Business Research, 5(1), 49-64.

LICHTENTHALER, U. ve ERNST, H. (2009). "The Role of Champions in the External Commercialization of Knowledge". Journal of Product Innovation Management, 26(4), 371-387.

LI-HUA, R. ve SIMON, D. (2007). "Benchmarking China Firm Competitiveness: A Strategic Framework". Journal of Technology Management in China, 2(2), 105-118.

LILIEN, G.L., MORRISON, P.D., SEARLS, K., SONNACK, M. ve VON HIPPEL, E. (2002). "Performance Assessment of The Lead User IdeaGeneration Process for New Product Development". Management Science, 48(8), 1042-1059.

LISBOA, A., SKARMEAS, D. ve LAGES, C. (2011). "Innovative Capabilities: Their Drivers and Effects on Current and Future Performance". Journal of Business Research, 64, 1157-1161.

LÜTHJE, C. ve HERSTATT, C. (2004). "The Lead User Method:An Outline of Empirical Findings and Issues for Future Research". R\&D Management, 34(5),553-568.

LYNN, G.S. ve AKGÜN, A.E. (2001). “Project Visioning: Its Compotents And Impact On New Product Success". Journal of Product Innovation Management, 18(6), 374-387.

MATHEUS, T. (2009). "A Conceptual Model and Illustrative Research Framework for Inter-Organizational Innovation". Management Research News, 32(3), 254-271. 
MATZLER, K., SCHWARZ, E., DEUTINGER, N. VE HARMS, R. (2008). "The Relationship between Transformational Leadership, Product Innovation and Performance in SMEs". Journal of Small Business and Entrepreneurship, 21(2), 139-152.

MCDERMOTT, C.M. ve O'CONNOR, G.C. (2002). "Managing Radical Innovation: An Overview of Emergent Strategy Issues". Journal of Product Innovation Management, 19(6), 424-438.

MEI, S. ve NIE, M. (2007). "Relationship Between Knowledge Sharing, Knowledge Characteristics, Absorptive Capacity and Innovation". The Business Review, Cambridge, 7(2), 154-161.

MOHR, J., SENGUPTA, S. ve SLATER, S. (2010). Marketing of HighTechnology Products and Innovations (Third Edition). New Jersey:Pearson Press.

MORRISON, P.D., ROBERTS, J.H. ve MIDGLEY, D.F., (2004). “The Nature of Lead Users and Measurement of Leading Edge Status". Research Policy, 33, 351-362.

MUSCIO, A. (2006). "Patterns of Innovation in Industrial Districts: An Empirical Analysis". Industry and Innovation, 13(3), 291-312.

NAIRN, A. (2002). "CRM: Helpful or Full of Hype?". Journal of Database Marketing, 9(4), 376-382.

O'CONNOR, G.C. ve AYERS, A.D. (2005). “Building A Radical Innovation Competency". Research Technology Management, 48(1), 23-31.

OLSON, E. ve BAKKE, G. (2001). "Implementing The Lead-User Method in a High Technology Firm: A Longitudinal Study of Intentions Versus Actions". The Journal of Product Innovation Management, 18(6), 388-395.

OLSON, E.L. ve BAKKE, G., (2004). "Creating Breakthrough Innovations by Implementing the Lead User Methodology". Telektronikk, 2, 126 132.

OTTENBACHER, M. ve HARRINGTON, R.J. (2007). “The Innovation Development Process of Michelin-Starred Chefs". International Journal of Contemporary Hospitality Management, 19(6), 444-460.

REID, S.E. ve DE BRENTANI, U. (2004). “The Fuzzy Front End of New Product Development for Discontinuous Innovations: A Theoretical Model". Journal of Product Innovation Management, 21(3), 170184.

REINDERS, M.J., FRAMBACH, R.T. ve SCHOORMANS, J.P.L. (2010). "Using Product Bundling to Facilitate the Adoption Process of Radical Innovations". Journal of Product Innovation Management, 27(7), 1127-1140. 
ROBERTS, N. (2009). Digitally Enhancing Customer Agility And Competitive Activity: How Firms Use Information Technology To Sense And Respond To Market Opportunities In Hypercompetitive Environments. (Ph.D.). Clemson University.

ROUPE, D. (2003). Channel Category Managers' Interrelationships and New Product Development Success. (Ph.D.). Portland State University.

SALAVOU, H. ve AVLONITIS, G. (2008). "Product Innovativeness and Performance: A Focus on SMEs". Management Decision, 46(7), 969985.

SANDSTRÖM, G.Ö. ve TINGSTRÖM, J. (2008). “Management of Radical Innovation and Environmental Challenges". European Journal of Innovation Management, 11(2), 182-198.

SCHREIER, M. ve PRÜGL, R. (2008). "Extending Lead-User Theory: Antecedents and Consequences of Consumers' Lead Userness". Journal of Product Innovation Management, 25(4), 331-346.

SHANI, A.B., SENA, J.A. ve OLIN, T. (2003). "Knowledge Management and New Product Development: A Study of Two Companies". European Journal of Innovation Management, 6(3), 137-149.

SHARP, B.M. (2009). Multilevel Absorptive Capacity And Radical Innovation. (Ph.D.). West Lafayette:Purdue University.

SPITHOVEN, A., FRANTZEN, D. ve CLARYSSE, B. (2010). “Heterogeneous Firm-Level Effects of Knowledge Exchanges on Product Innovation: Differences between Dynamic and Lagging Product Innovators". Journal of Product Innovation Management, 27(3), 362-381.

SUBRAMANIAM, M., (2006). "Integrating Cross-Border Knowledge for Transnational New Product Development". Journal of Product Innovation Management, 23(6), 541-555.

SWAN, K.S., KOTABE, M. ve ALLRED, B.B. (2005). “Exploring Robust Design Capabilities, Their Role in Creating Global Products, and Their Relationship to Firm Performance". Journal of Product Innovation Management, 22(2), 144-164.

TELLIS, G.J., PRABHU, J.C. ve CHANDY, R.K. (2009). “Radical Innovation Across Nations: The Preeminence of Corporate Culture". Journal of Marketing, 73(1), 2-23.

TINOCO, J.K. (2007). Accomplishment of Dual Focus in Exploration and Exploitation: The Influential Role of The Customer Relationship Management (CRM) Process. (Ph.D.). The University of Central Florida. 
TORKKELI, M., ELFVENGREN, K., KARKKAINEN, H. ve TUOMINEN, M., (2002). "Lead User Method with Group Support System-Need Assessment for New Wireless Technologies", 12th International Working Seminar on Production Economics, February, ss.18-22.

UZKURT, C. (2008). Pazarlamada Değer Yaratma Aracı Olarak Yenilik Yönetimi ve Yenilikçi Örgüt Kültürü. İstanbul:Beta Basım Yayım.

VAN DER BIJ, H., SONG, X.M. ve WEGGEMAN, M. (2003). "An Empirical Investigation into the Antecedents of Knowledge Dissemination at the Strategic Business Unit Level". Journal of Product Innovation Management, 20(2), 163-179.

VAN KLEEF, E., VAN TRIJP, H.C.M. ve LUNING,P., (2005). “Consumer Research in the Early Stages of New Product Development: A Critical Review of Methods and Techniques". Food Quality and Preference, 16, 181-201.

VERMEULEN, P.A.M. (2005). “Uncovering Barriers to Complex Incremental Product Innovation in Small and Medium Sized Financial Services Firms". Journal of Small Business Management, 43(4), 432-452.

VINCENT, L.H., BHARADWAJ, S.G. ve CHALLAGALLA, G.N. (2004). "Does Innovation Mediate Firm Performance?: A Meta-Analysis of Determinants and Consequences of Organizational Innovation", Unpublished Manuscript.

VON HIPPEL, E. (2005). Democratizing Innovation. London:The MIT Press.

VORHIES, D. ve MORGAN, N. (2005). "Benchmarking Marketing Capabilities for Sustainable Competitive Advantage". Journal of Marketing, 69(1), 80-94.

WEI, Y. (2006). Market Orientation and Successful New Product Innovation: The Role Of Competency Traps. (Ph.D.). The University of North Carolina.

WEN, H.J., YEN, D.C., ZENG, Y.E. (2003). “Customer Relationship Management (CRM) in Business-to-Business (B2B) E-Commerce". Information Management \& Computer Security, 11(1), 39-44.

YALCINKAYA, G., CALANTONE, R. ve GRIFFITH, D. (2007). "An Examination of Exploration and Exploitation Capabilities: Implications for Product Innovation and Market Performance". Journal of International Marketing, 15(4), 63-93.

YANG, J. (2010). “The Knowledge Management Strategy and its Effect on Firm Performance: a Contingency Analysis". International Journal of Production Economics, 125(2), 215-223.

YAYLA, A.Y. ve YILDIZ, A. (2010). “Lider Kullanıcı Metodunun Ürün Geliştirme Performansına Etkisi ve Uygulama".i.T.Ü Dergisi D Serisi, Mühendislik, 9(2), 3-12. 
A. ERCIŞ, P. CAN $\mid 66$

ZACHARIA, Z.G. (2001). An Analysis of The Effect of Logistics Involvement in Cross-Functional Integrated New Product Development Projects. (Ph.D.). Knoxville:The University of Tennessee.

ZHENG ZHOU, K., YIM, C.K. ve TSE, D.K. (2005). "The Effects of Strategic Orientations on Technology- and Market-Based Breakthrough Innovations". Journal of Marketing, 69(2), 42-60. 